\title{
THE ROLE OF EDUCATIONAL SUPERVISORS IN DEVELOPING THE FIRST TEACHERS' JOB PERFORMANCE IN THE LIGHT OF THE GOAL SUPERVISION MODEL AT THE GOVERNORATE OF MUSCAT SCHOOLS: A FIRST SUPERVISOR'S PERSPECTIVES
}

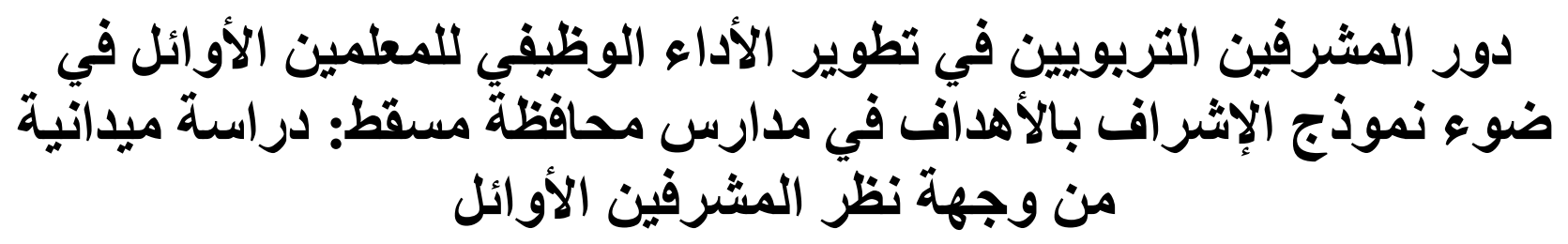

$$
\text { إبراهيم بن علي بن مبارك الحديدي }
$$

Ibrahim Ali Mubarak Alhadidi ${ }^{1 \star}$ \& Dawood Abdulmalek Yahya Al-Hidabi ${ }^{2}$

${ }^{1}$ Ph.D. Candidate at the Faculty of Education, International Islamic University Malaysia (IIUM); ebrheem99@moe.om

${ }^{2}$ Prof. Dr. at the Faculty of Education, International Islamic University Malaysia (IIUM); dawood@iium.edu.my

${ }^{*}$ Corresponding Author

\begin{abstract}
This qualitative study discussed the first educational supervisors' perspectives in developing the job performance of the first teachers, due to the objective's supervision model at Muscat Governorate schools. The statement problem was the absence of the educational supervisors' role in the developing of the first teachers' performance, and the weakness of goals supervision application. The objective of the study: to discuss the role of educational supervisors in developing the first teachers' job performance in the light of supervision model, the study adopted the descriptive qualitative approach, using the interviews for data collection. The study sample were (4) supervisors at the General Directorate of Education in Muscat. The findings revealed that; the role of educational supervisors in developing the job performance of the first teachers was high of the goal supervision model; On the existence of a (high) estimate in the fields of (implementation, field follow-up, and evaluation), and on a (average) to relatively low estimate in the areas of (goals, planning) in some of the goals and plans.
\end{abstract}

Keywords: educational supervisors, first teachers, goal supervision<smiles>[Mg][Mg]</smiles>

ناقثت هذه الدراسة النوعية وجهة نظر المشرفين التربوبين الأوائل في تطوير الأداء الوظيفي للمعلمين الأوائل، في ضوء نموذج الإشراف بالأهداف بمدارس محافظة مسقط. تمثلت مشكلة

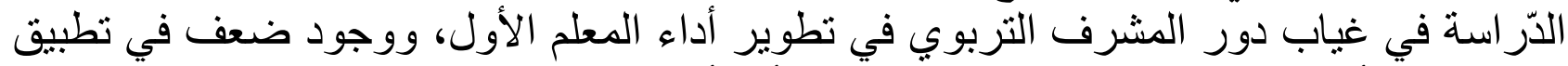

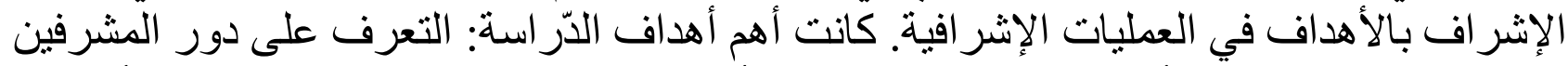
التربوبين في تطوير الأداء الوظيفي للمعلمين الأوائل في ضوء نموذج الإشراف بالأهداف، 
اعتمدت الدّراسة المنهج الوصفي (النوعي) لتحقيق أهدافها، وتم استخدام المقابلة كأداة لجمع البيانات، حيث تكون مجتمع الدّر استة من المشرفين والمثرفئ الثات الأوائل بالمديرية العامة للتربية و التعليم بمحافظة مسقط، وقد تم إجراء المقابلات مع (4) مشرفين ومشرفات أو ائل لأجل جمع البيانات، وقد أظهرت استجابات المشرفين الأوائل حول دور المشرفين التربويين في تطوير الأداء الوظليفي للمعلمين الأو ائل في ضوء نموذج الإشر اف بالأهداف؛ عن وجود تقدير (عالِّ) في مجالي (التفيذ و المتابعة الميدانية، و التقويم)، و عن تقدير (متوسط) إلى متدني نسبيًا في مجالي (الأهداف، التخطيط) في بعض الأهداف و الخطط. كلمات مفتاحية: المشرفين التربوبين، المعلمين الأوائل، الإشر اف بالأهداف

\section{المقدمة}

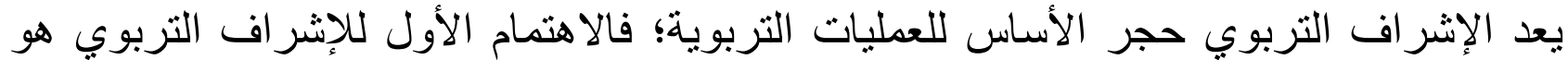
تحسين عمل المعلمين، والرقي بمستواهم المعرفي والمهني، وتوفير الإمكانات بما يخدم العملية

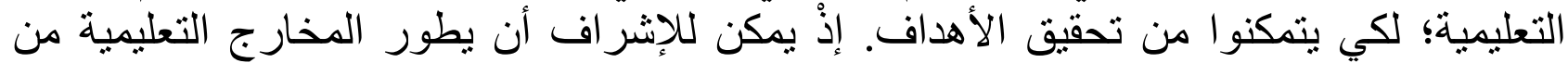
خلال التدريب العملي و الفعال، و التقويم المناسب، وتقديم التغذية الر اجعة الجيدة، وتحسين ظروف

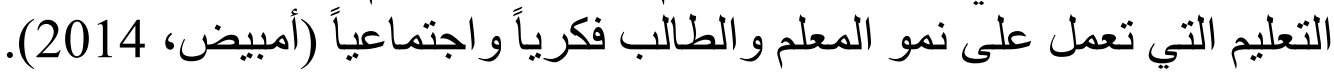
وللإشر اف مكانة كبيرة ور اسخة كطريقةٍ معروفة وشائعة التطبيق في كل المنظمات و المؤسسات التعليمية و غيرها، وله جذور طويلة في المجال التعليمي، وفي دعم العملية التعليمية، والتطوير

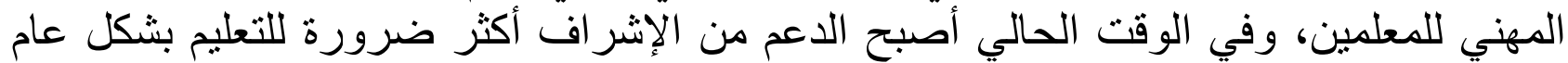

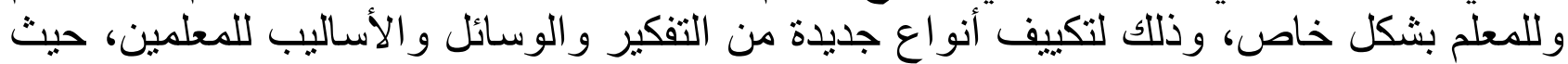

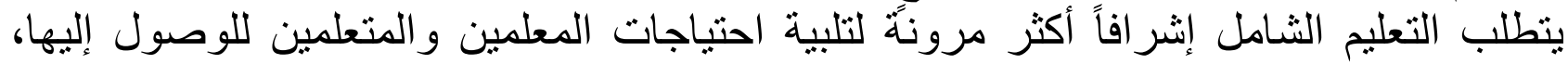
وتفعيل عمليات التقييم و التطوير، حيث يتم تطوير المجتمعات التعليمية من خلال التعاون المهني و التفكير، وتمكين الأسـاليب الجيدة و الفعالة (Määttä \& Alila, 2016).

وكما تشير الدّر اسات و البحوث التربوية العديدةكدراسات (القبلان، 2018؛ الطعان، 2016؛

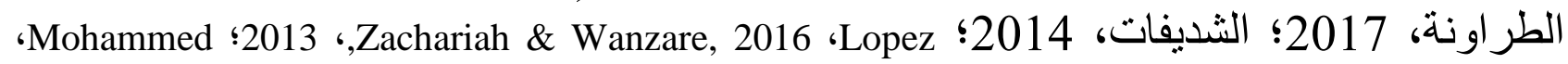

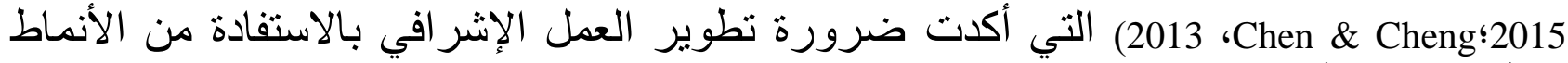
و الأساليب والأنشطة الإشرافية الحديثة، والتي تهدف إلى تطوير كفاءات المعلمين والمعلمين الأوائل في الميدان التربوي، و العمل على حفز التّقدم المهني و الفني لدئهي لديهم.

وبلا شك فإن مدارسة المشرفين التربويين للاتجاهات والأنماط الحديثة المعاصرة للإشراف التربوي تهدف بشكل أساسي إلى رفع المستوى الفني و المهني للمعلمين الأوائل و المعلمين، وتزيد

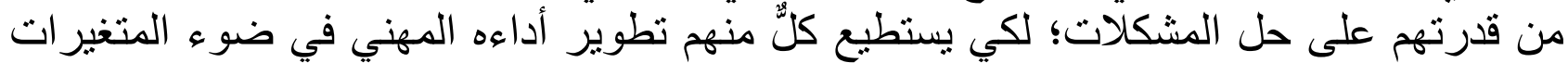
التربوية الحديثة، وكذلك تزيد من دافعية المعلمين للعمل، وزيادة فاعلية العملية التعليمية (الأبيض و الرويلي، 2017). وينفرد نموذج الإشر اف بالأهداف باعتباره أحد اتجاهات الإشر اف التربوي المعاصرة بمميز ات 
كبيرة، كقدرته على زيادة كفاءة وفاعلية الإشراف التربوي في تطوير وتحسين العمليات التعليمية

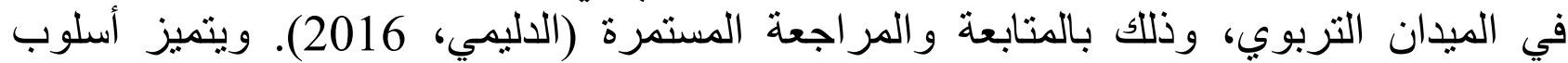

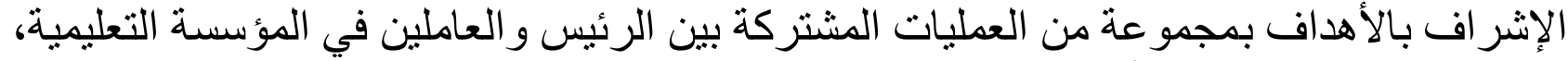

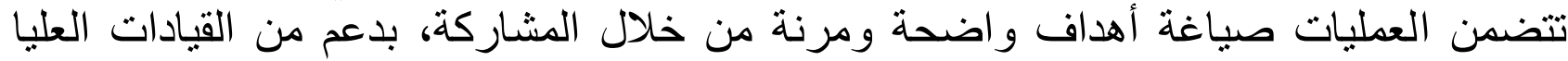

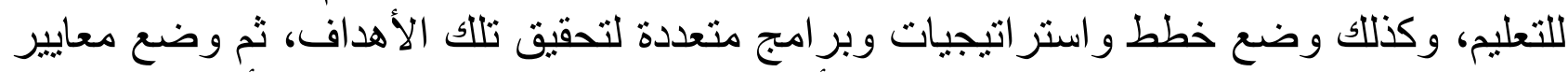

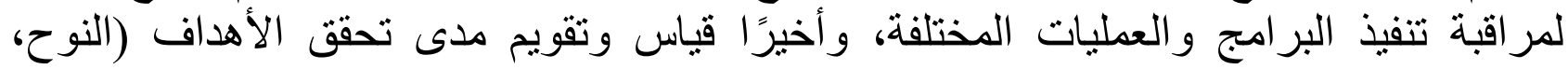
.(2011

وقد أكد العديد من الباحثين في دراساتهم (الثمري، 2017؛ الحربي، 2008؛ النوح، 2011؛

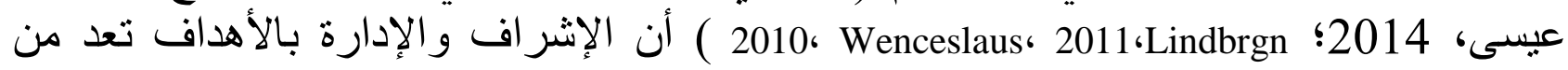

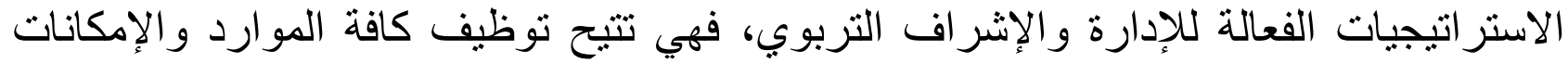

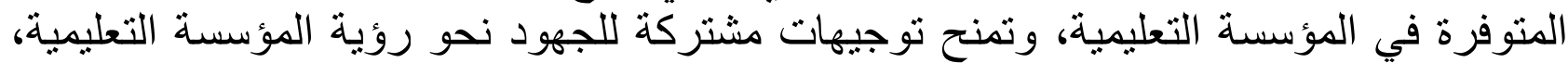
وتعمل على خلق روح الفريق الو احد لتحقيق الأهداف المشتركة تونة

مشكلة البحث ع ماثى

يثير العديد من الباحثين في دراساتهم مثل دراسة (العامري، 2008؛ الفهدي وآخرون، 2014؛

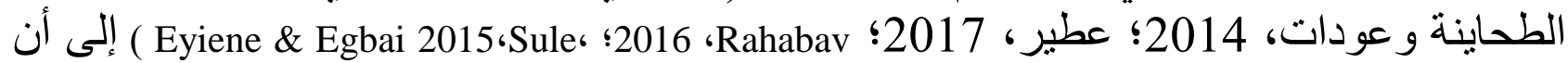

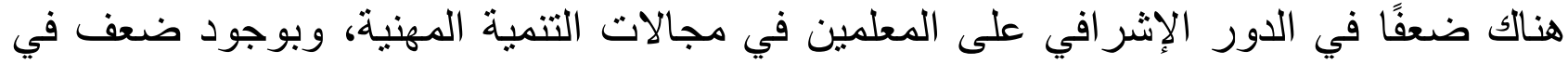

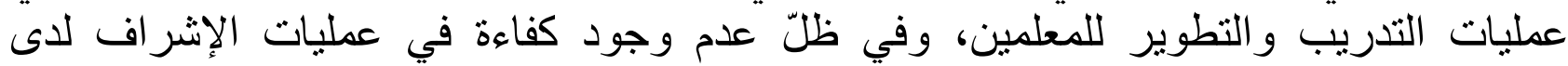

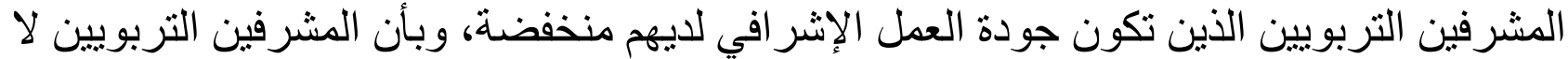

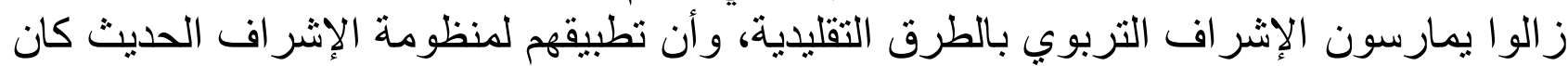

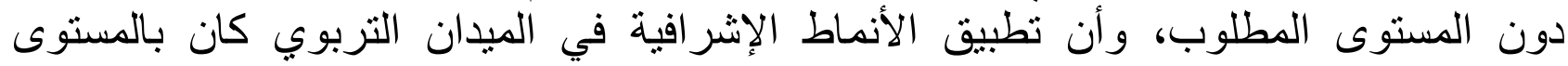
الضعيف.

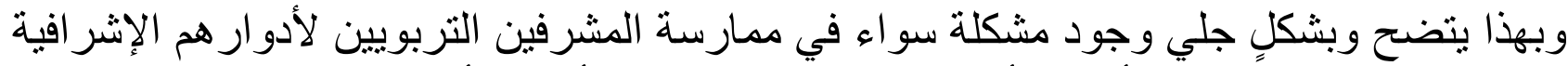

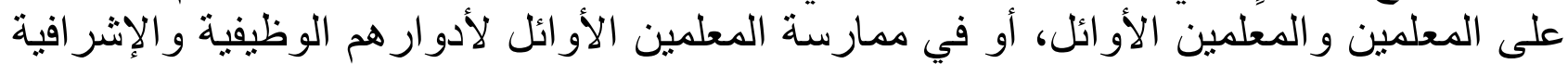

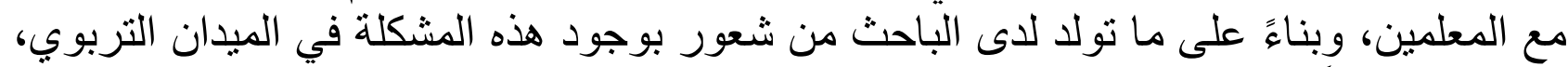

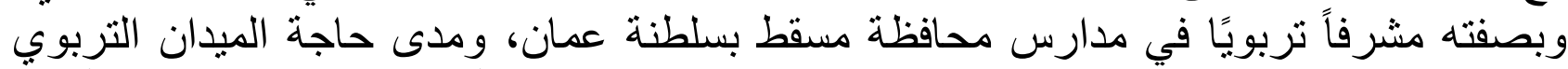

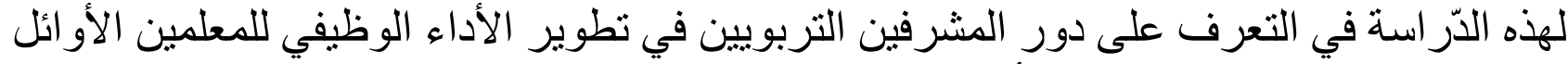

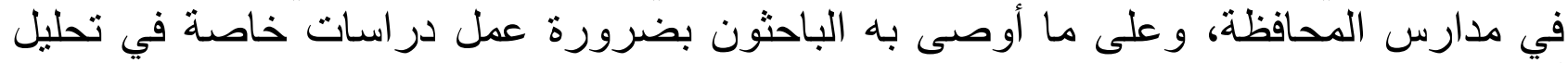

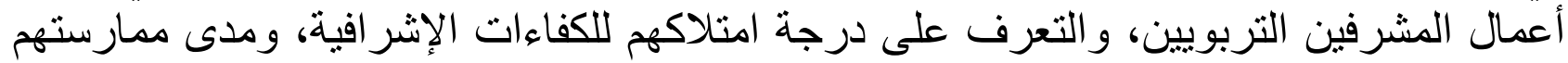

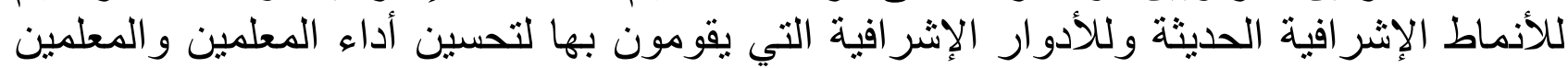
الأو ائل في مهار اتهم ومهامهم الفنية و المهنية. هدف الدراسة

مناقشة دور نمط الإشراف بالأهداف للمشرفين التربويين، في تطوير الأداء الوظيفي للمعلمين الأو ائل، بمدارس محافظة مسقط في سلطنة عمان.

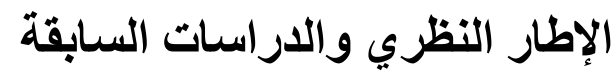
الإشر اف بالأهداف: 
الإشر اف بالأهداف كما عرفه جون (jong S.jun) هو عملية يتم بو اسطتها وضع أهداف المؤسسة

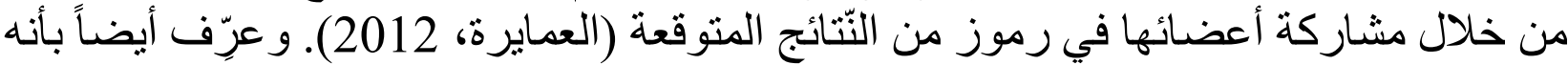

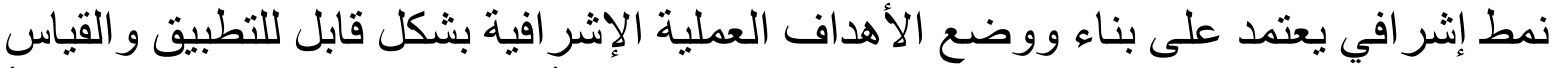

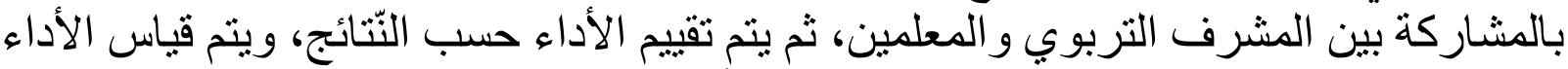
بإعطاء المعلم الدرجة وفق المقياس المعد لذلك (الأبيض و الرويلي، 2017) يعتبر الإثر اف بالأهداف نموذجاً إثر افياً جديداً، يعمل لمواكبة التغيرات في الأنظمة التعليمية

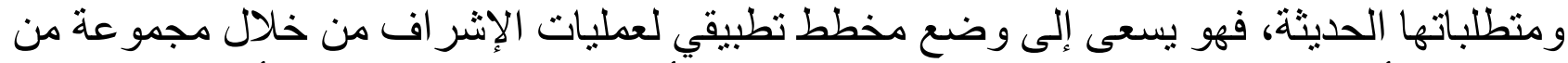

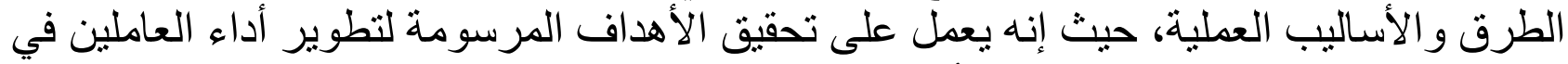
المبدان التربوي، من خلال وضع الأهداف، و عمل الخطط المختلفة، وتحديد البرامج التنفيذية، ومتابعة تتفيذها بشكل دوري ومباشر، ثم تقويم تتفيذ البرامج على حسب اعب الأهداف المرسومة، و إعطاء تغذية راجعة لتحسين وتطوير لتوري الأداء.

وقد ذكر الثمري (2017) أن أسلوب الإشر اف بالأهداف يؤدي دور إهاماً في تحسين العملية التعليمية عبر الاستفادة القصوى من الموارد البشرية، وذلك بتطوير القدر ات و المهار ات ات للعاملين في الميدان التربوي، وتحفيز هم على الابتكار و المبادأة، ورفع قدرتهم في التصدي للمني لمعيقات

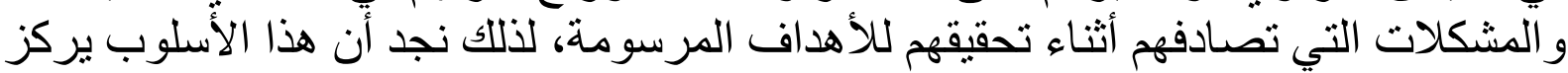
بشكل كبير على العناصر البشرية باعتبار ها الأداة الأهم في سبيل تحقيق الأهداف، من خلال ربط مصالح الأفر اد بمصالح المؤسسة. مراحل وخطوات تطبيق نموذج الإثراف بالأهداف: وضع بيتر دركر (Drucker) أربع مر احل، هي:

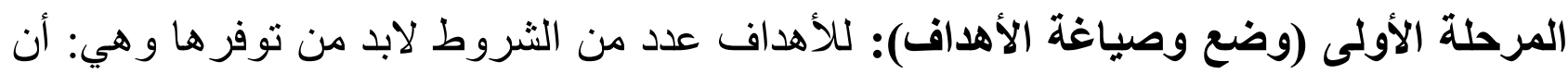

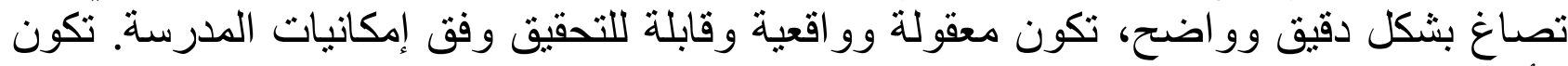

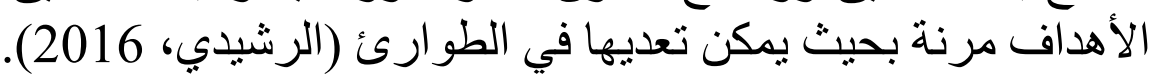

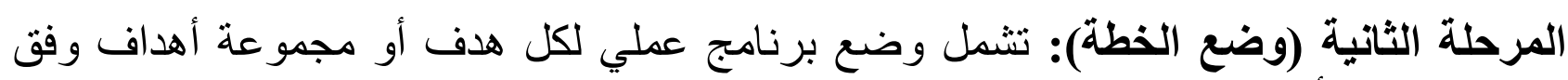

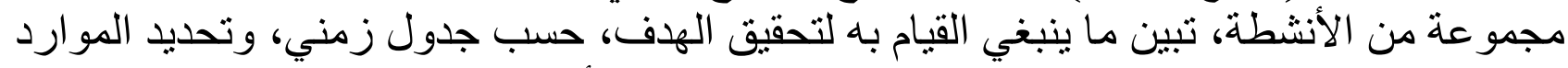

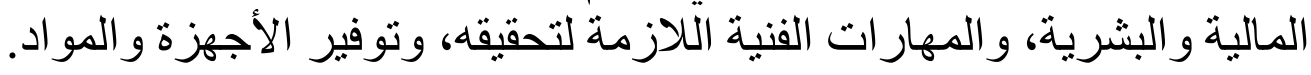
المرحلة الثالثة (التنفيذ والمتابعة الميدانية):

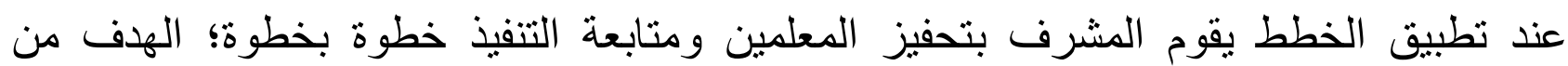

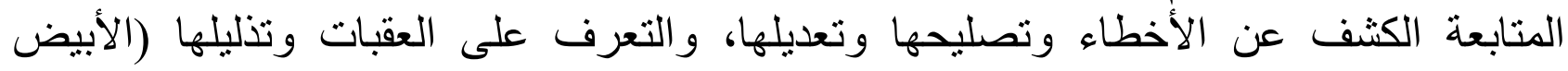

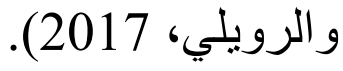
المرحلة الرابعة (التقويم وقياس الإنجاز): لا بدَّ من قياس الإنجاز لمعرفة ما إذا كانت النّائج

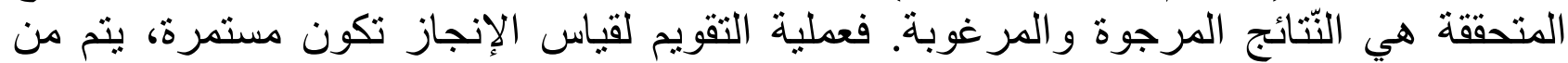

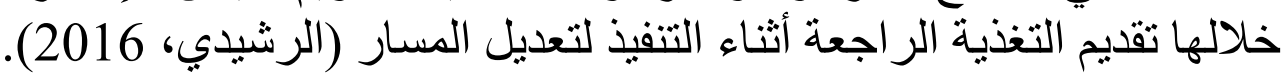
الاراسات السابقة دراسة الرشيدي (2016): التي هدفتْ التعرف على واقع وفاعلية تطبيق نموذج الإشراف 
بالأهداف على العملية التعليمية في دولة الكويت، واستخدم الباحث المنهج الوصفي لأغر اض فئه در استه، ولكي يحقق أهداف در استه قام بتطوير استبانة تتكون من (39) فقرة موزعة على على ثلاثة محاور، حيث وزعت الاستبانة على عينة الدّر اسة المكونة من (292) من المدراء وراءئه المشرفين

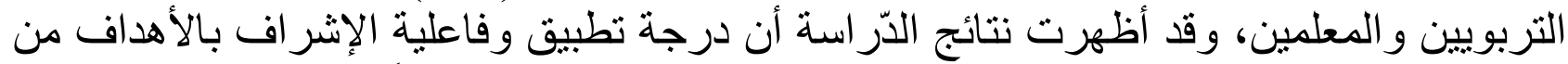

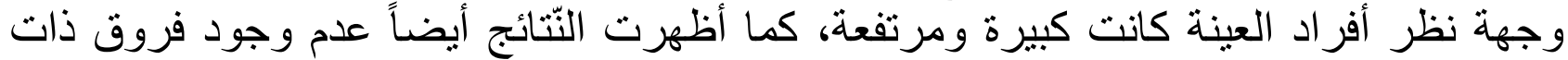
دلالة إحصائية بين متوسطات استجابات أفراد العينة حول درجة فاعلية وتطبيق الإشراف بالأهداف على العملية التعليمبة تبعاً لمتغيرات (الوظيفة، و الجنس، وسنوات الخئه الخبرة)، كما قدم الباحث مجمو عة من التوصيات كان من أهمها تعميم تطبيق نموذج الإشر اف بالأهداف على جميع المناطق في دولة الكويت.

دراسة الكلباني (2016): بعنوان مدى ممارسة المشرفين التربوبين لبعض أنماط الإشراف التربوي في مدارس التعليم الأساسي بمحافظة الوسطى بسلطنة عمان، والتي كان هدفها الكثيف مدئ عن مدى الممارسة التي يقوم بها المشرفين التربوبين لبعض أنماط الإشر اف في في مدارس التعليم

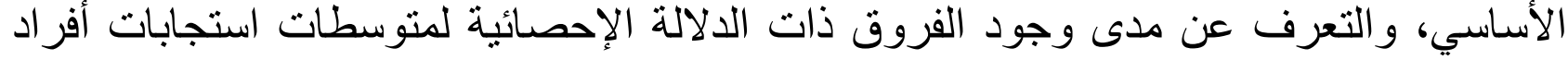

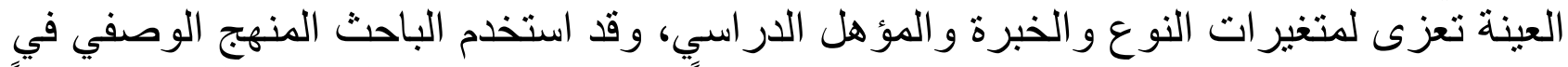
در استه، وقام باختيار عينه نتكون من (261) معلماً ومعلمة من محافظة ولة الوسطى، مستخدماً

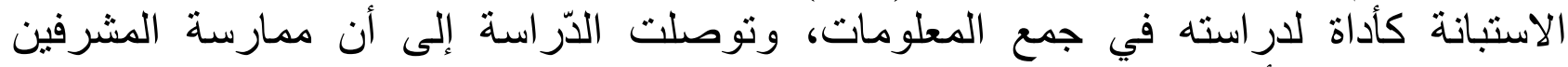

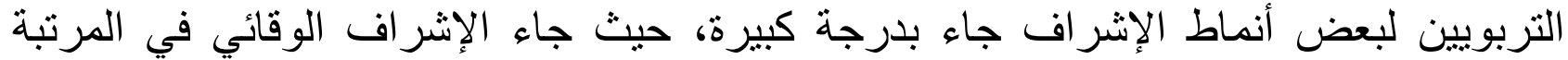

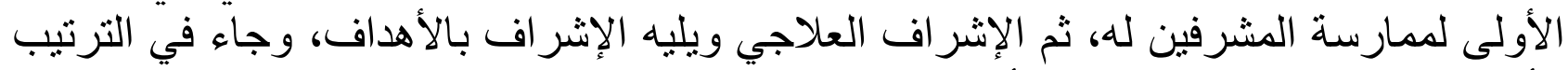
الأخير نمط الإشراق الإبداعي، و أظهرت الذّراسة وجود فروق ذات دلالة إحصائية في إجابات

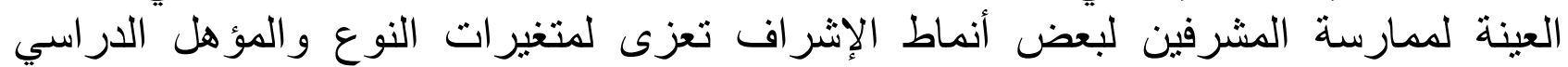
و الخبرة.

دراسة (2011) (Lindbrgn) "أثر الإدارة بالأهداف في إدارة المدارس الثانوية على المدارس الثانوية بالسويد، وتأثثر الإجهاد و الكفاءة الذاتية على المدر أَ"، و التي كان هدفها التعرف على على أثر الإدارة

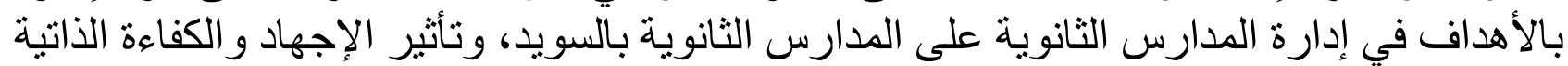
على المدر اء، و اتخذت الدّر اسة المنهج شبه التجريبي، وكذلك المنهج التاريخي، وذلك من خلال توزيع الاستبانات في فترنين منباعدنين على المدراء في المدارس الثانوية العليا، وتوصلت نتائج الدّر استة إلى أن هنالك أهمية في تطبيق الإدارة بالأهداف على الجى الجانب الاقتصادي للمعلمين، و أنه لكي تقوم إدارة المدرسة بتطبيق الإدارة بالأهداف لابد الأبد لها من النظر للجانبين الاقتصادي و الاجتماعي للمعلمين، وأن تطبيق الإدارة بالأهداف لها تأثير إيجابي على المعلمين في تللك المدارس.

\section{منهج الدراسة وإجراعاتها:}

استخدم الباحث المنهج الوصفي النوعي، ويعرف المنهج الوصفي بأنه شكل من أشكال التحليل العلمي المنظم لوصف الظاهرة أو المشكلة التي تم تحديدها للحصول على معلومات دقيقة عن

الظاهرة (الكسباني، 2012).

مجتمع الدراسة وعينتها: 


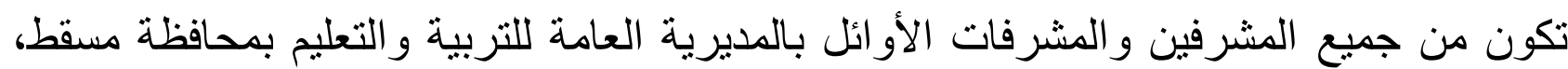
البالغ عددهم (6) مشرف ومشرفة أول. وقد تم أخذ عدد الخد (4) منهم وهم الذين نم تثنيتهم في مهنة مشرف أول مادة.

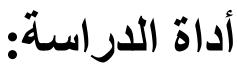

تم صياغة أسئلة المقابلة المفتوحة التي تقع في أربع مجالات هي: (الأهداف، التخطيط، التنفيذ

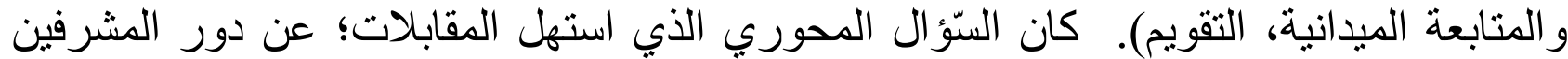

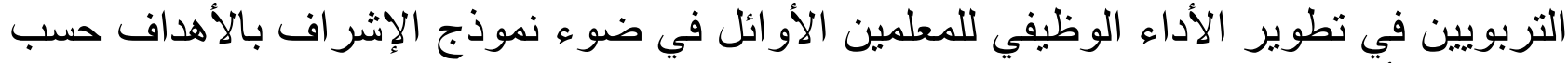

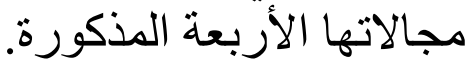

\section{الطريقة والإجراءات في تطبيق أداة المقابلة} قام الباحث بالتو اصل مع المشرفين الأوائل لتحديد زمان المقابلة ومكانها، وأخذ إذن للتسجيل الصوتي للمقابلة:

- تفريغ المقابلة الصوتية إلى نصوص مكتوبة، وذللك بالاعتماد على برنامج Word Microsoft. - تجزئة النصوص إلى وحدات ذات معنى مفهوم، وذلك لتسهيل عملية الترقيم و الترميز. - مر اجعة البيانات و المعلومات، وربطها بالسيّؤ ال الرئيسي للأدر اسة. - - صياغة تلك البيانات و المعلومات إلى نتائج الدّر اسة. عرض النتائج وتفسير ها:

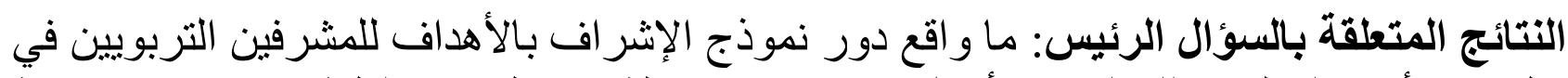

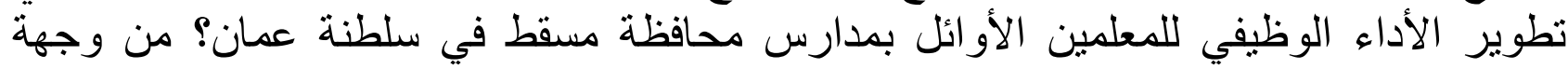
نظرك؟

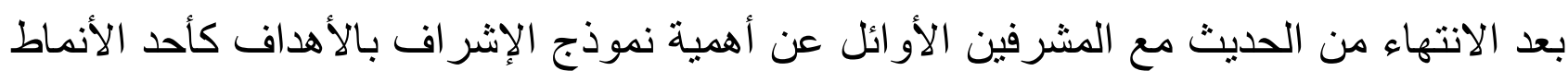

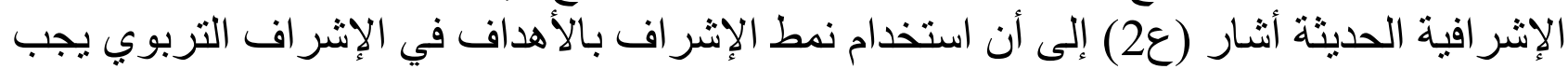

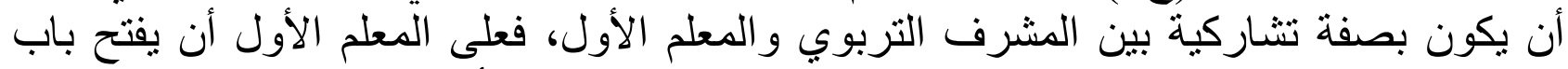

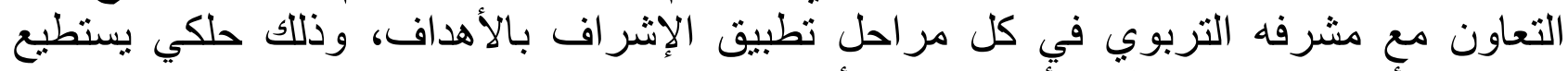

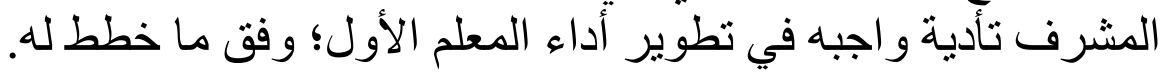

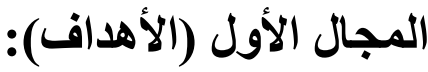

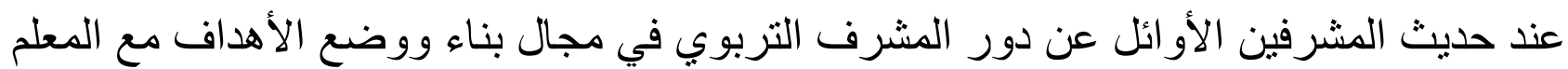

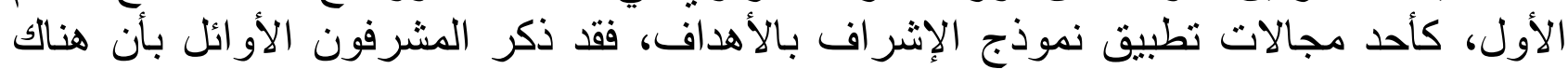

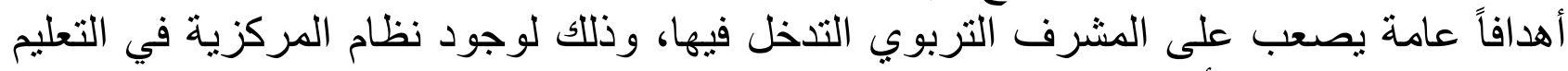

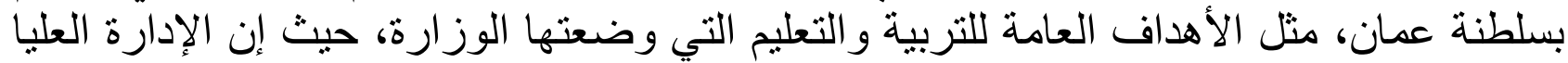

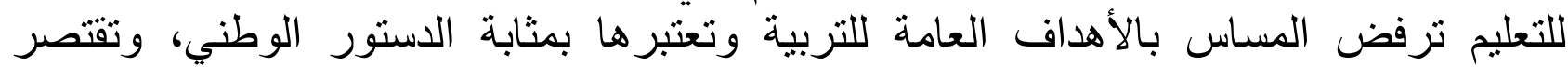

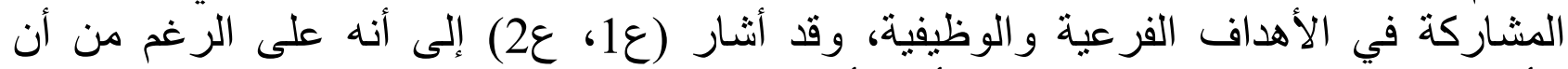

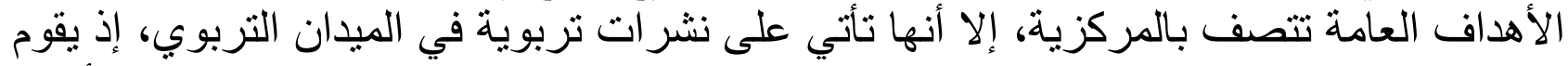

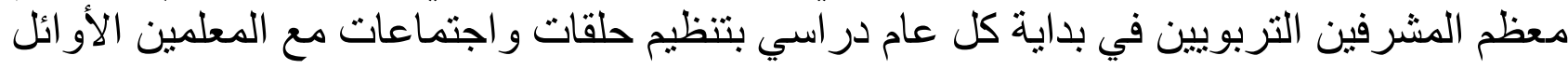


والمعلمين، ويقومون خلالها بقر اءة تللك النشرات، وتوضيح أهدافها للمعلمين، وذللك لكي يكونوا

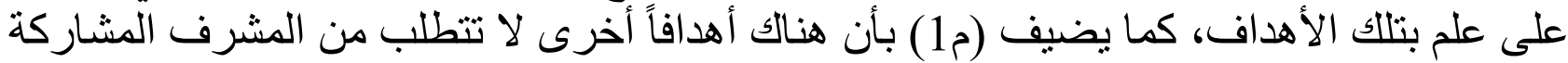

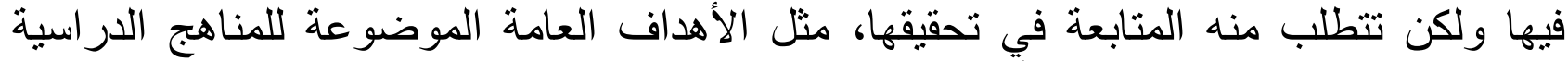

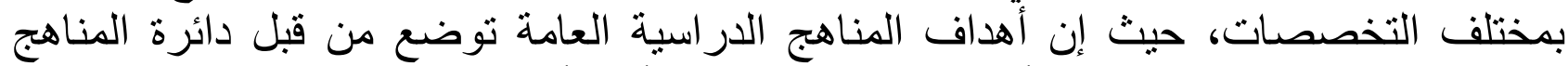

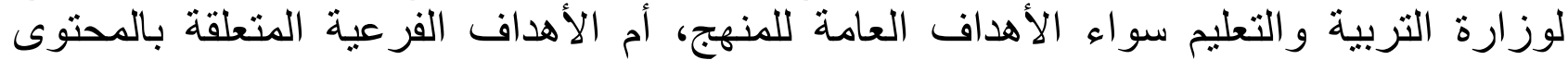
للمناهج، وقد أضاف أن المشرف التربوي يتابع فقط تحقيق تللك الأهداف مع المعلم الأف الأول.

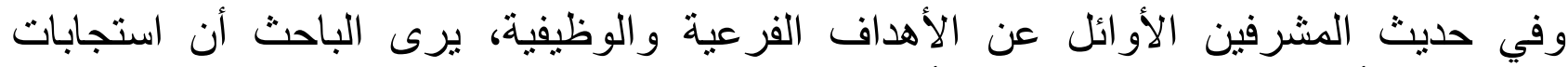

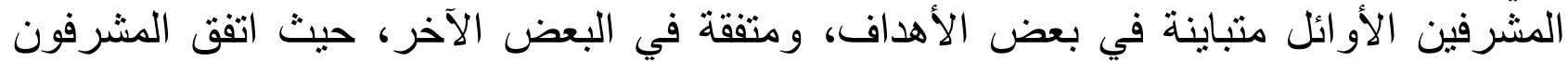

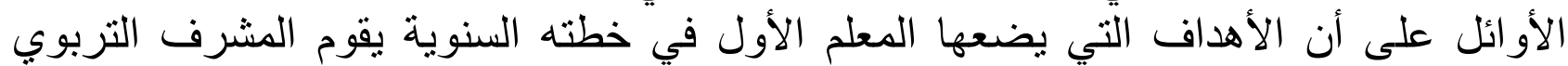

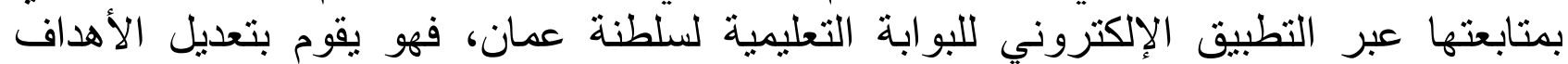

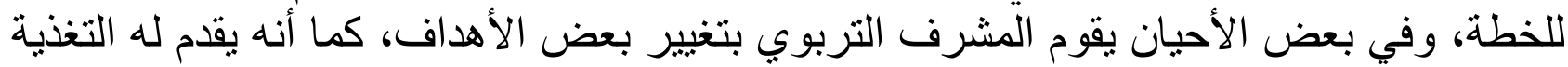

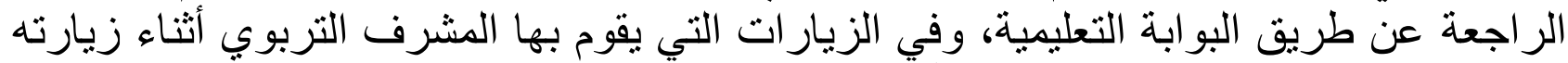

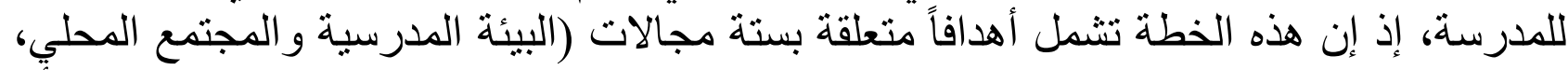

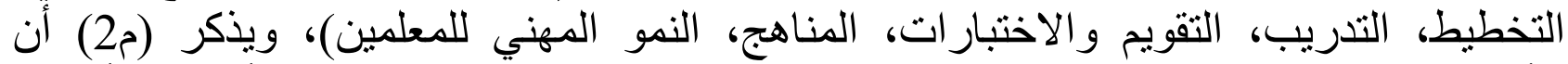

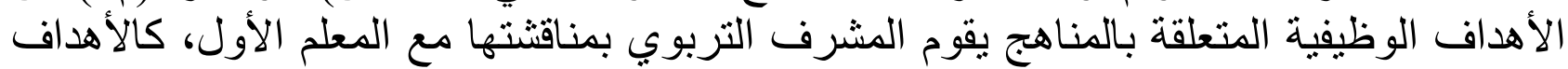

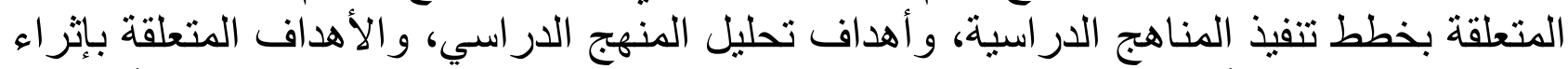

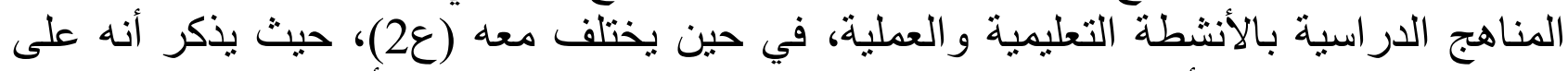

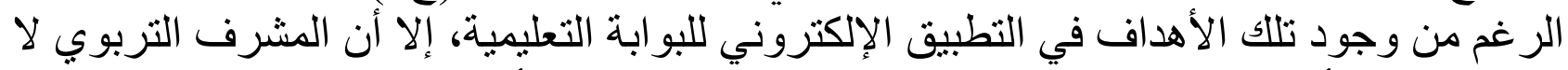

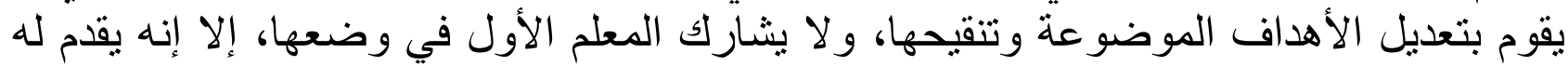

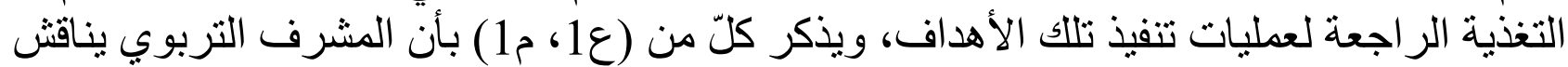

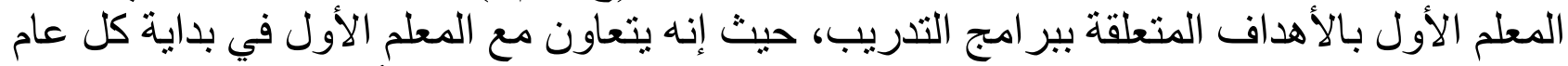

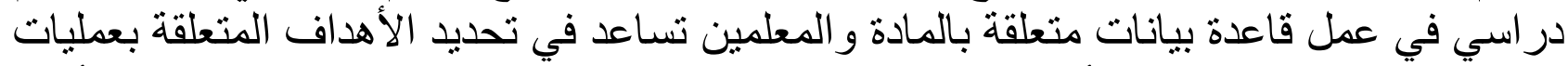

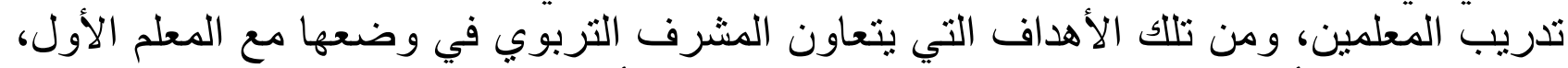

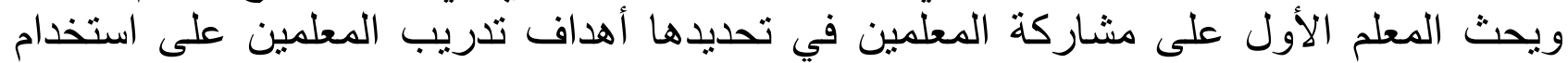

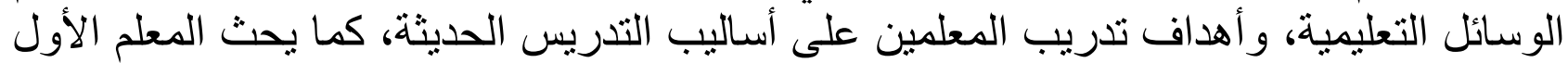

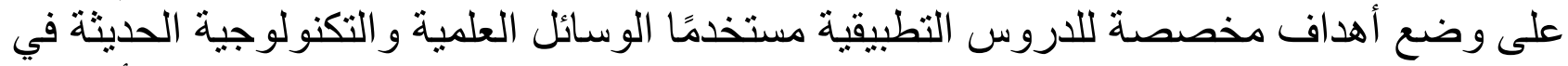

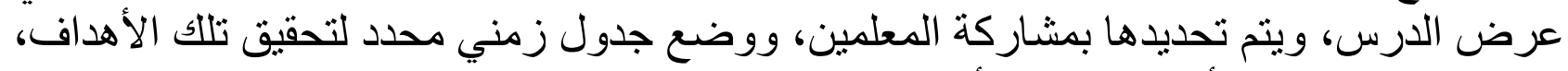

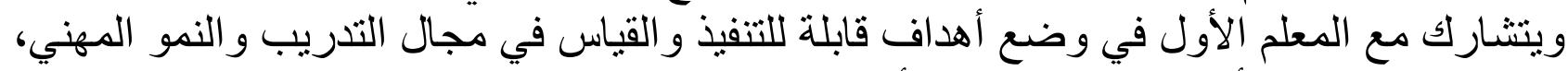

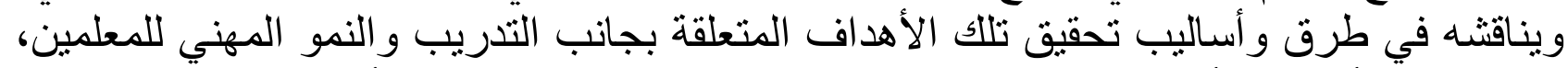

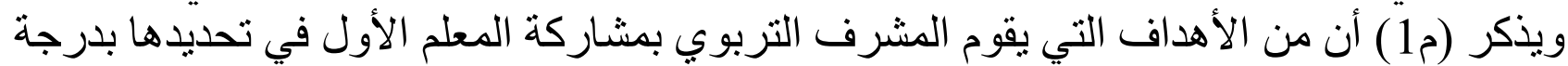

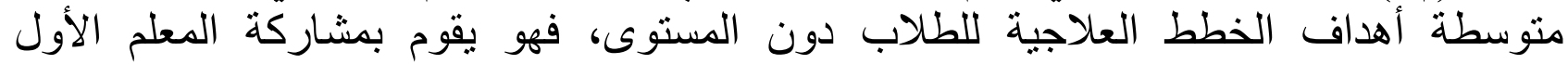

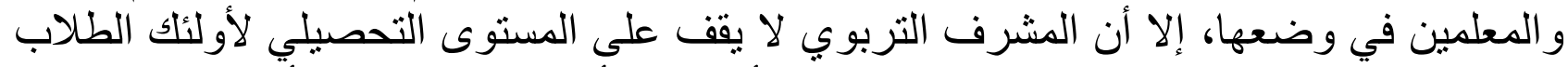

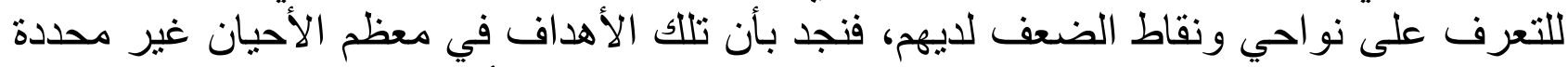

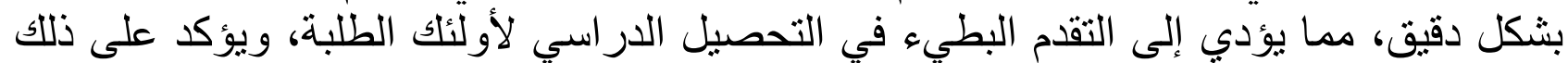

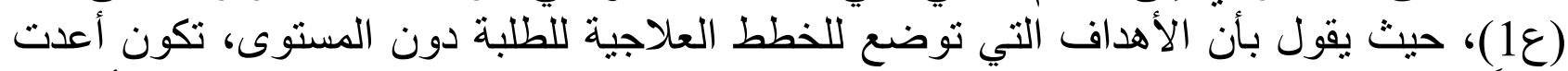

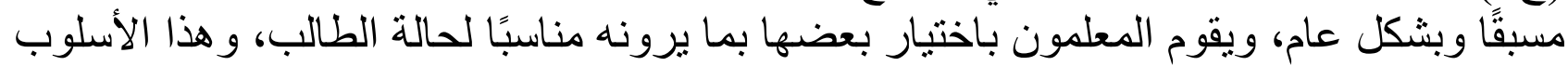

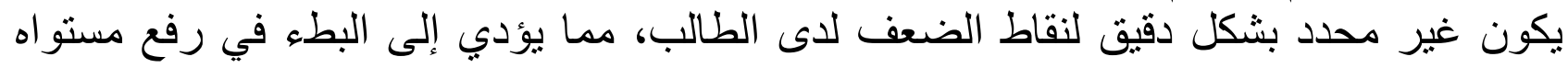




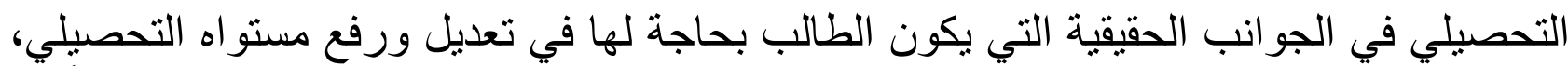

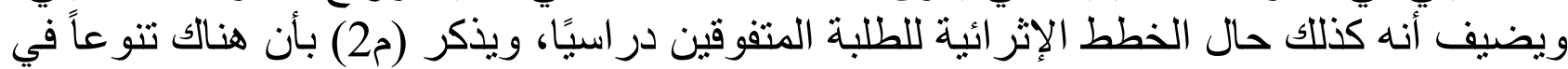

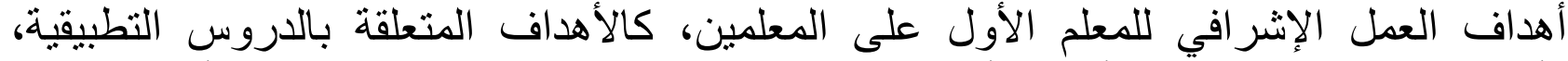

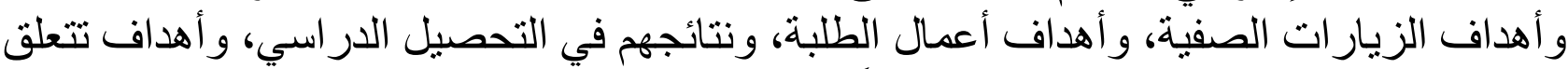

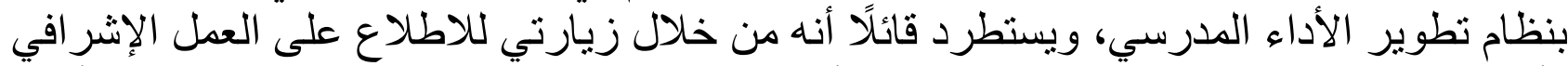

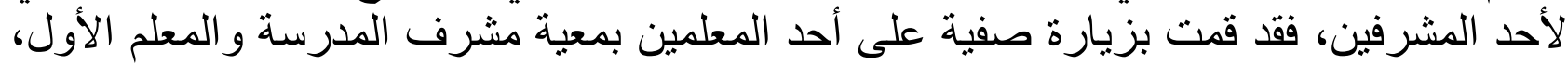

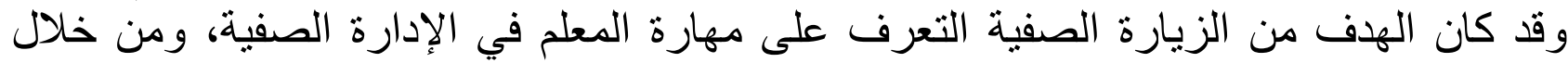

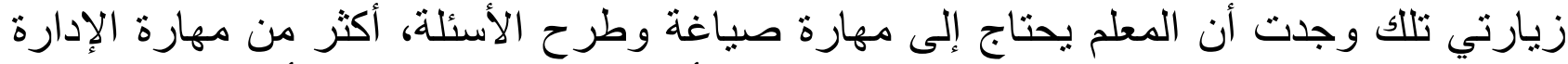

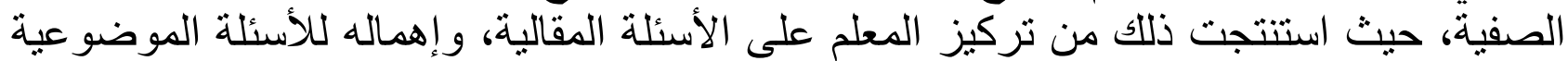

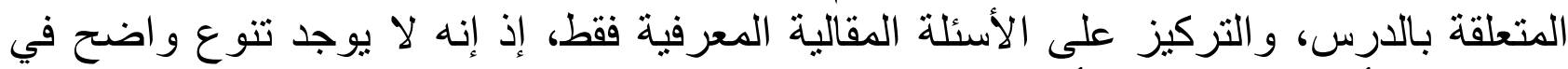

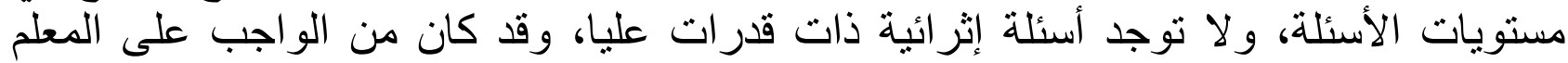

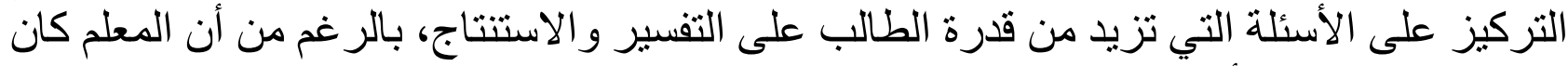
قوي الثخصية، وله أساليب إدارية فعالة مئ فع الطلبة.

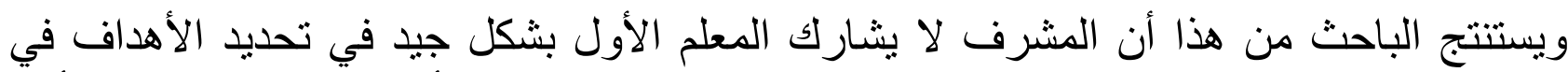

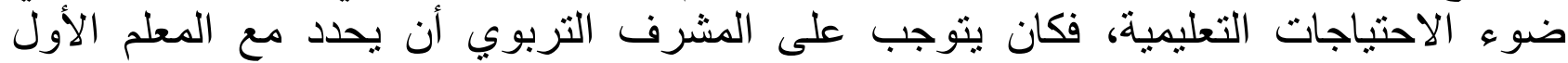

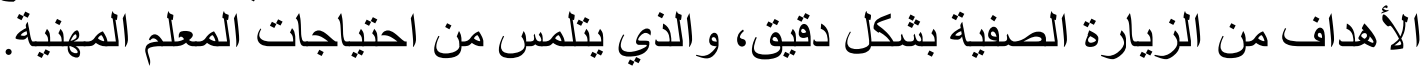

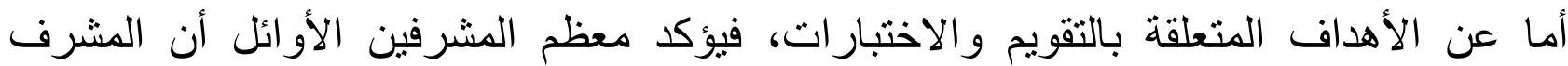

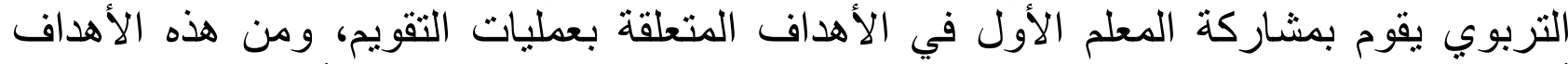

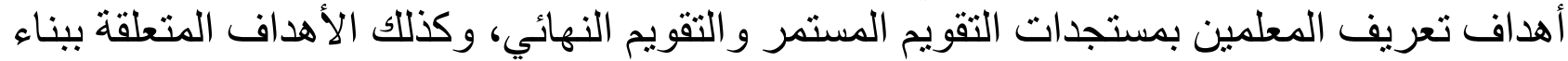

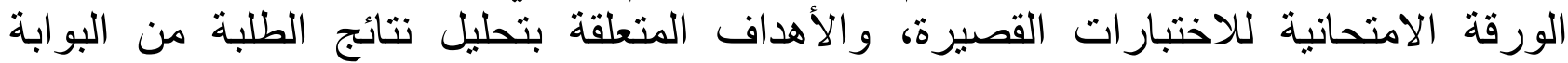
التعليمية، و الأهداف المتعلقة بتوظيف نتائج التحليل لرفع المستوى التحهيلي لإني للطلاب.

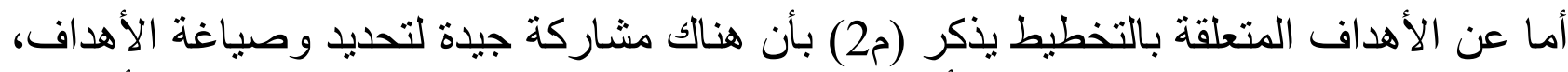

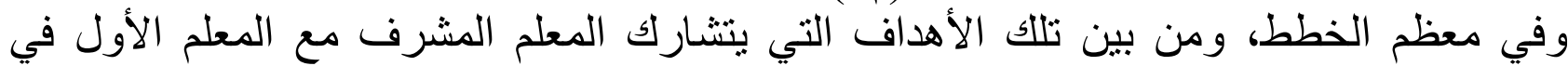

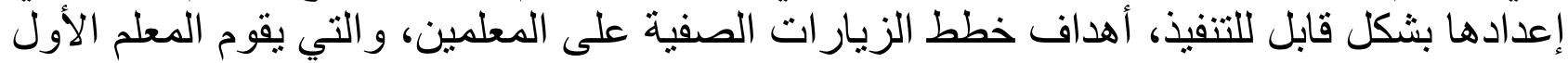

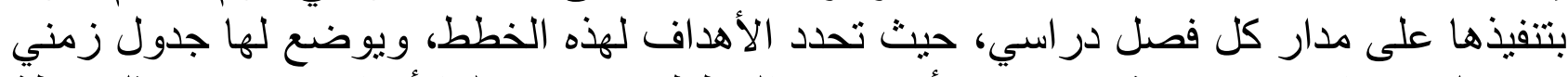

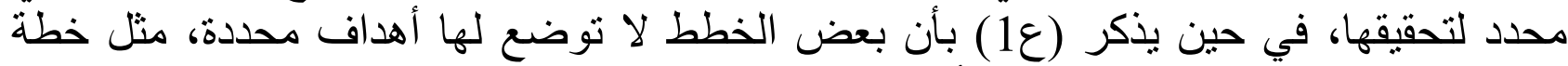

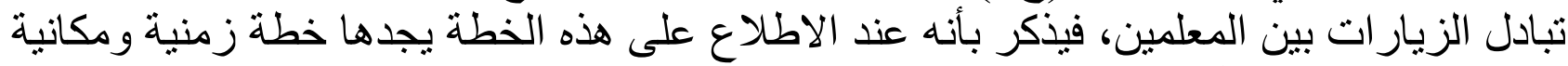

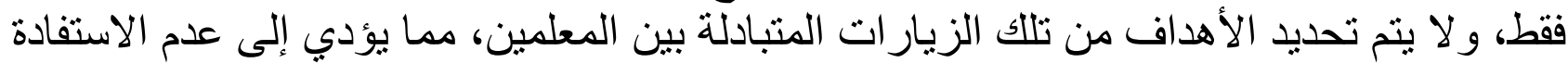

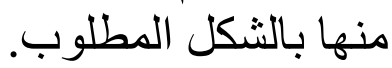

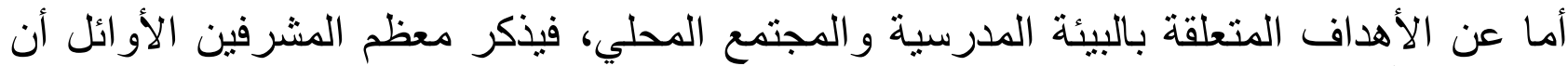

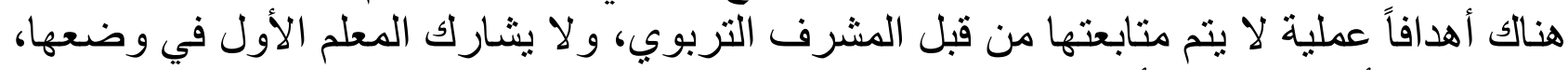

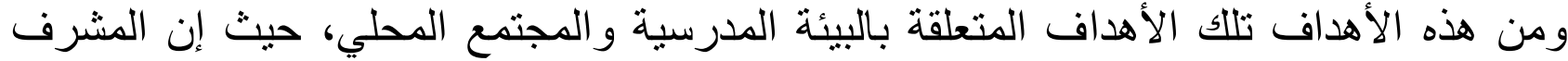

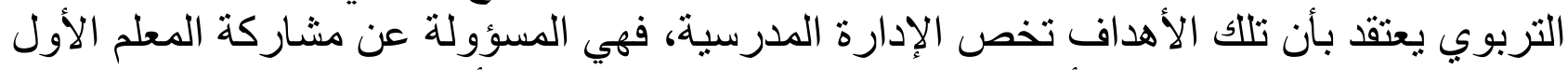

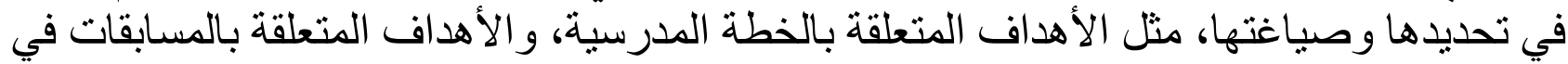

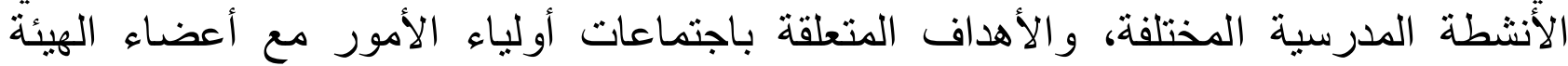
الإدارية و التدريسية بالمدرسة. 


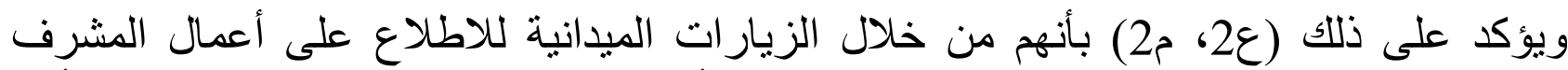

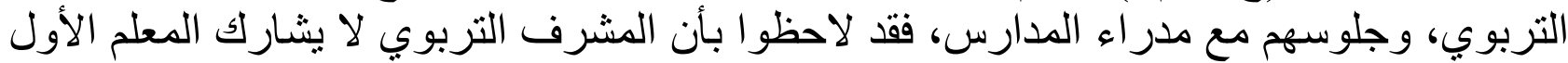

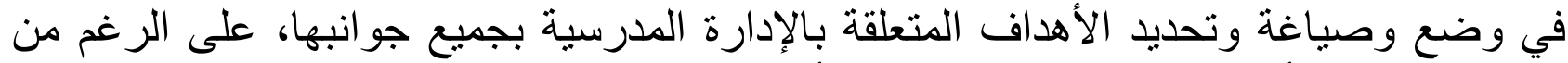

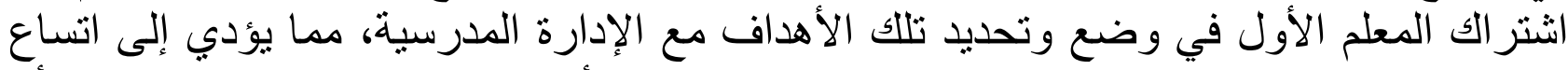

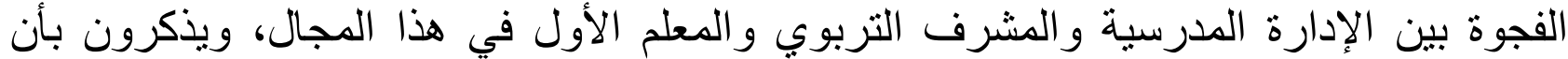

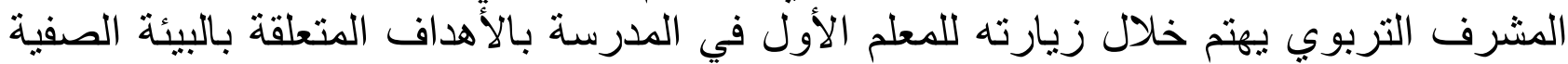
و الطلاب، و الأهداف المتعلقة بالجانب العملي للمعلمين على مستوى الألى المادة فقط.

وذكر المشرفون الأوائل أن مرحلة وضع الأهداف للخطط المختلفة، تصاحبها بعض التها التحديات

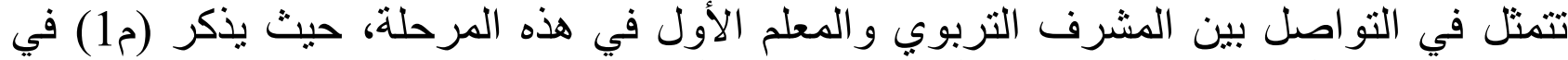

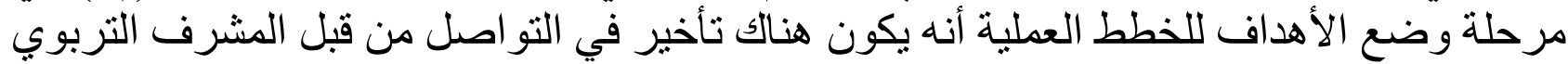

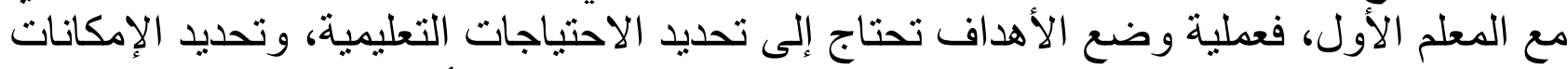

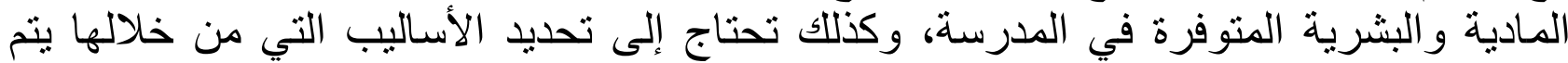

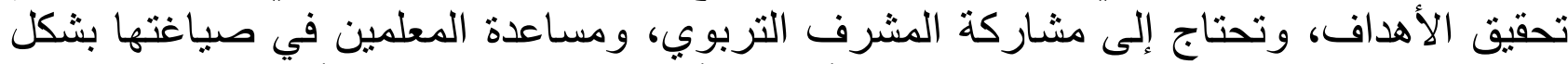

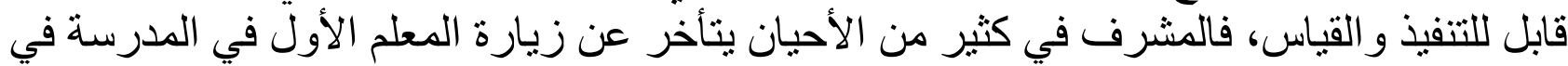

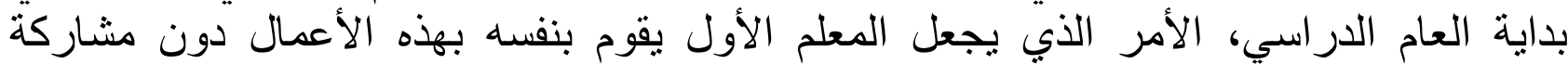

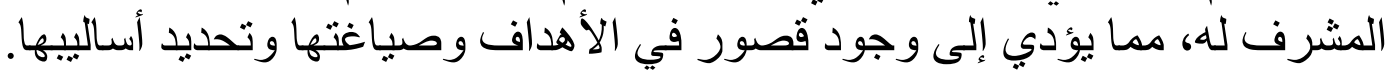

المجال الثاني (التخطيط):

ذكر المشرفون الأو ائل بأن عملية وضع الخطط تكون موازية لعملية وضع الأهداف، فهي تتم في

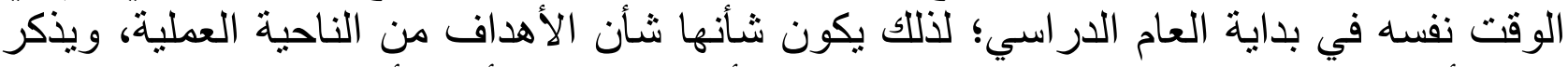

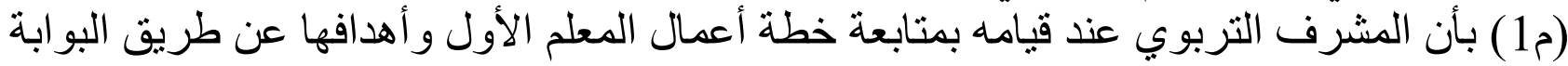

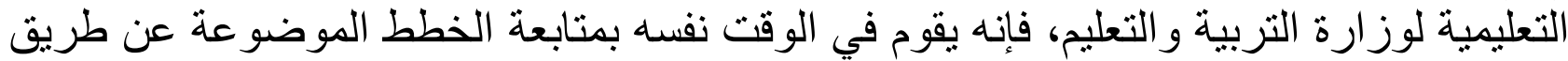

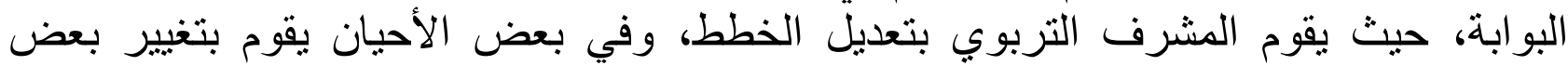

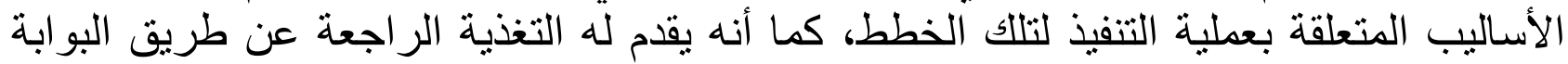

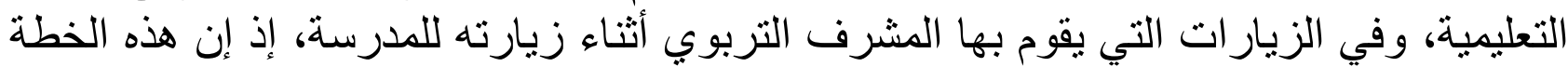

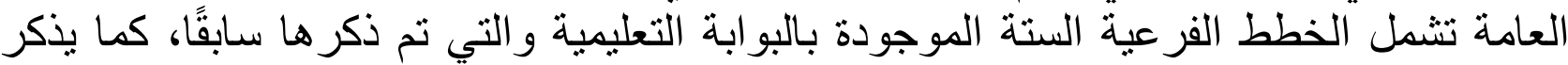

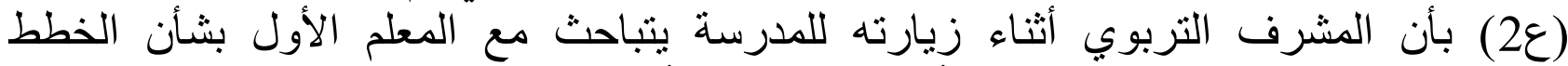

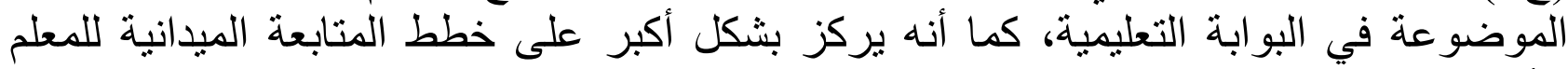

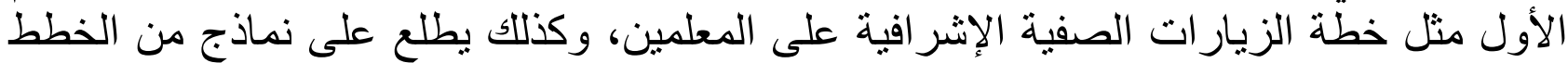

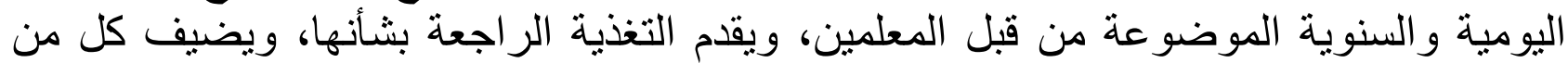

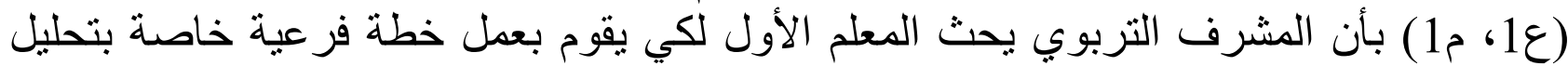

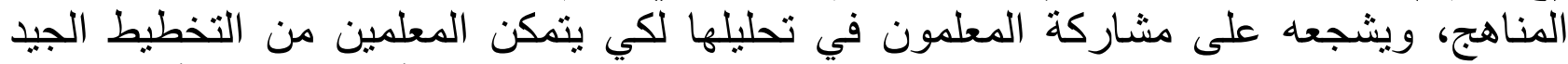

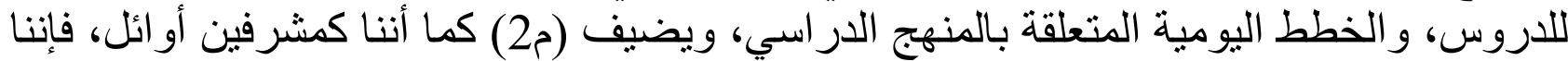

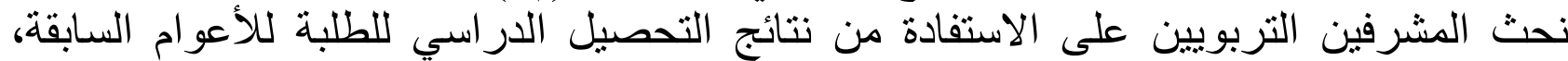

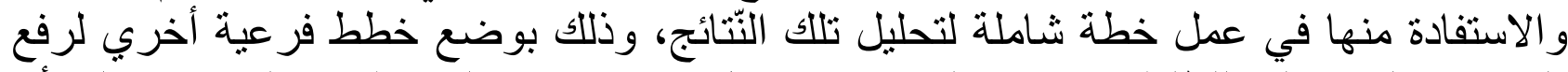

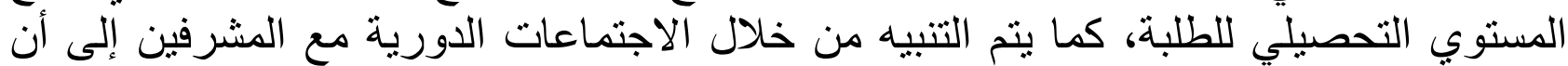

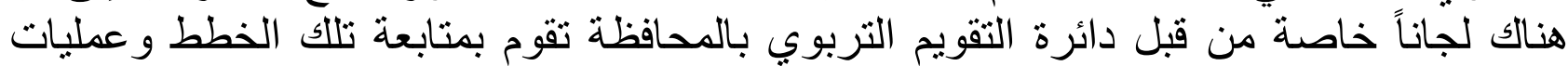


تتفيذها، ويستطرد قائلاً بأن معظم المشرفين التربويين يقومون بتلك الإجراءات المتعلقة بخطط

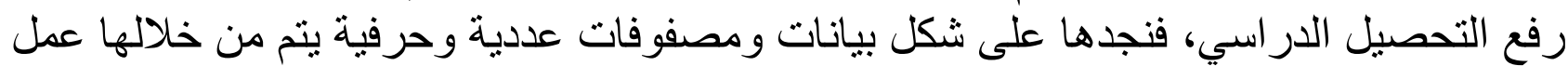
الخطط اللازمة لرفع مستوى التحصيل الدراسي للطلاب، ويشير (م1، ع2) إلى أن خطط رفع

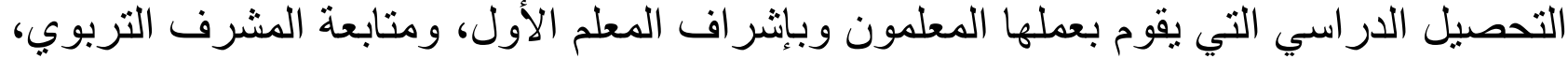

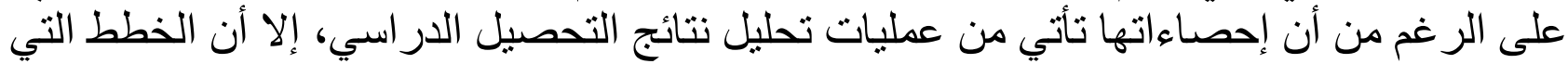

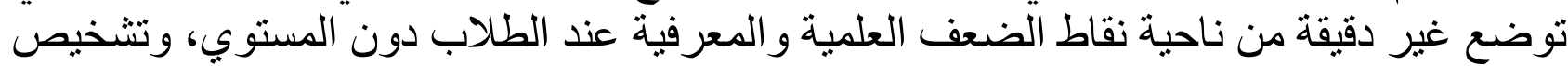
الطلاب غير دقيق فيها، إذ نجد أن المعلمين يضعون الأسئلة المتعلقة بنلك الخطط من بنك الأسئلة

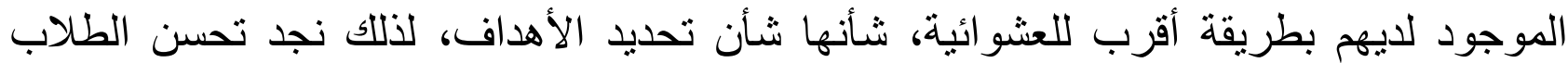
بطيء في المستوى التحصيلي لديهم، ويضيف كلّ من (ع1، م2) بأنهم ومن خلال متابعتهم

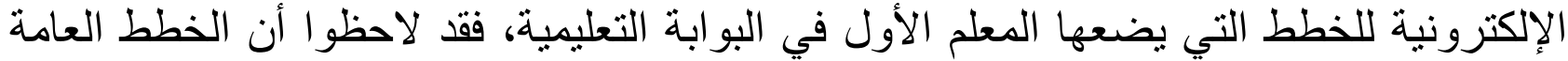
بمجالاتها المختلفة موجودة ومرفوعة في موقع البوابة التعليمية الخاص بوزارة التهارة التربية و التعليم، و أنه يوضع لها جدول زمني لتنفيذها، ومحددة الوسائل التي يتم استخدامها في عملية التنفيذ، ولكنتا نجد أن تلك الخطط بيقصها بعض الإجراءات، منثل تحديد معايير الأداء لقياس عمليات التتفيذ،

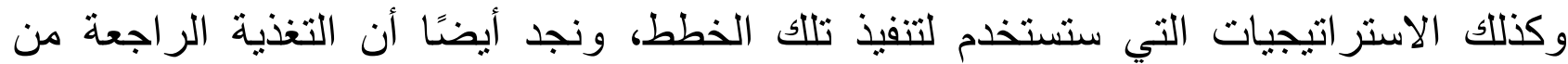
المشرف التربوي للمعلم الأول لا توضح تللك الإجراءات بشكل كافي ودقيق، و عند سؤال

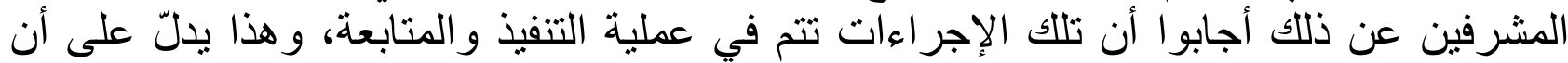

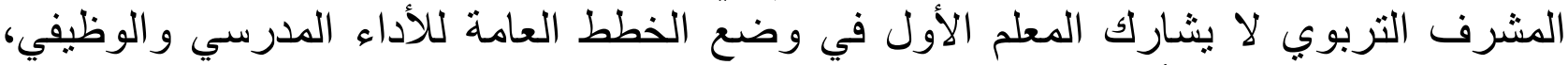
ويؤكد على ذلك (ع2) بأنه من خلال متابعته للخطط الخاصة بالبيئة المدرسية و المجتمع المحلي عبر البوابة التعليمية يجد أن تلك الخطط موضوعة بشكل عشوائي، ومنكرر تقريبًا في كل عام

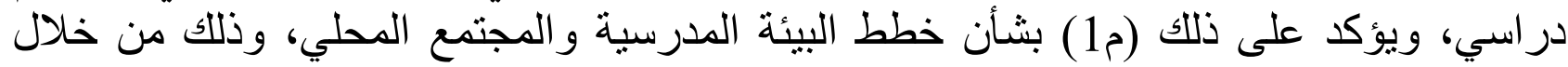

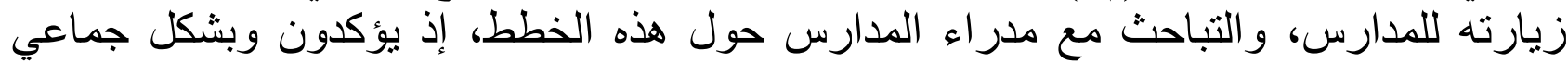
تقريبًا على أن المشرف لان يقوم بما يلزم عمله بشكل جيد بما يخص هذه الخطط.

أما بشأن الخطط الفرعية فإن جميع المشرفين الأوائل يؤكدون أن هناك نشاطاً ومشاركة ملموسة للمشرف التربوي في تللك الخطط وإعدادها بشكل عام، وتقديم التغذية الراجعة للمعلم الأول

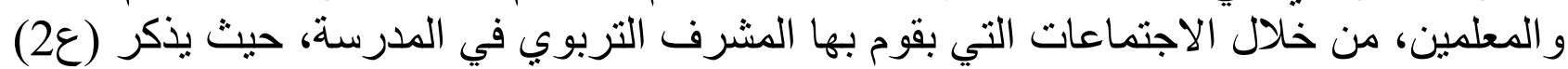
بأن المشرف التربوي يتباحث مع المعلم الأول حول خطة الدروس التطبيقية، والتي تكون موضو عة بجدول زمني محدد خلال كل فصل در اسي، وييلغ عددها عند بعض المشرفين سبعة

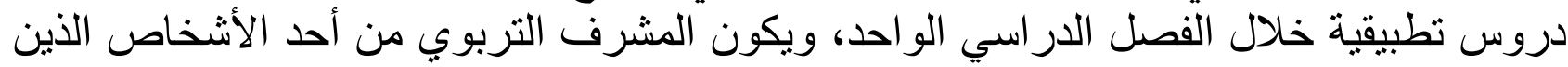

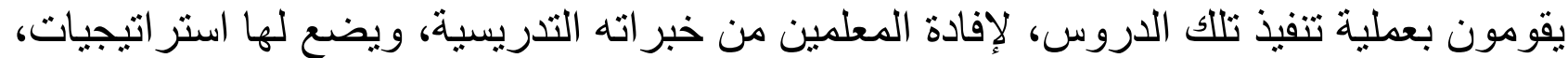

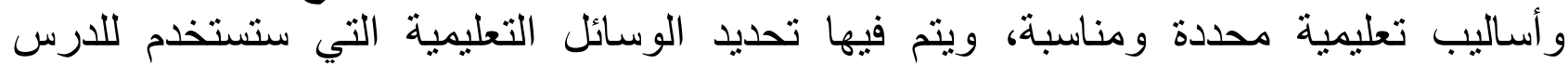

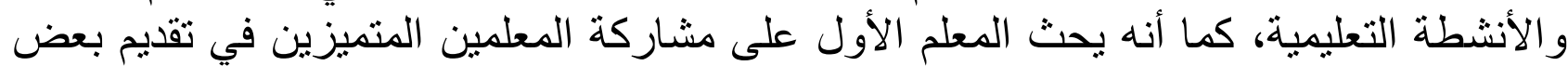
الدروس التطبيقية، ويذكر (م2) أن من الخطط التي يحرص المشرف فيها بمشاركة المعلم الأول خطط التقويم، حيث يقوم المشرف التربوي بالاجتماع مع المعلم الأول لتنظيمها، ووضنع الجداول الزمنية اللازمة لعملية التقويم، ويحرص المشرف التربوي على على أن تكون تلك الخطط مكتملة،

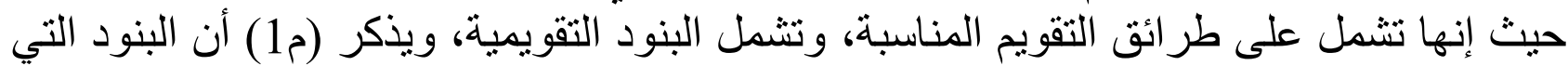

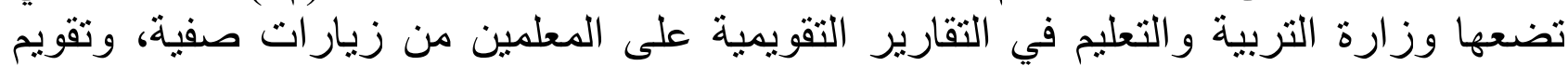

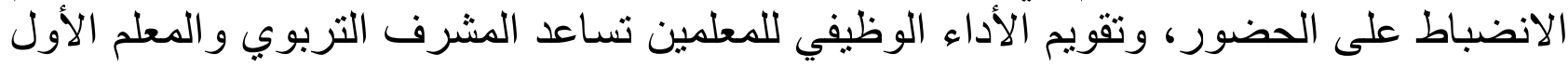


في التعاون لوضع خطة شاملة لعملية تقويم المعلمين، والإجراءات والأساليب التي ينبغي على التئي

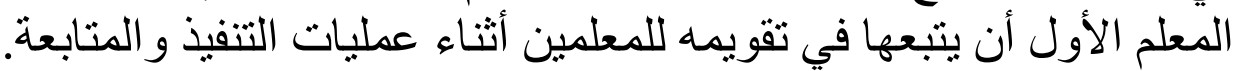

وذكر المشرفون الأوائل بأن من الخطط التي يساعد المشرف التربوي في وضعها ومشاركة

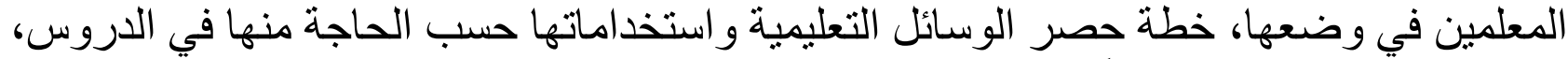

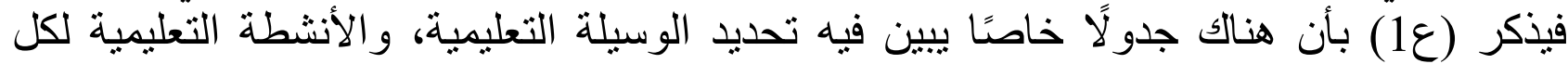

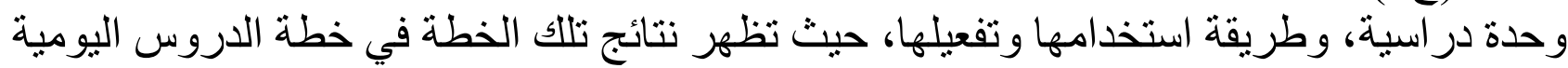

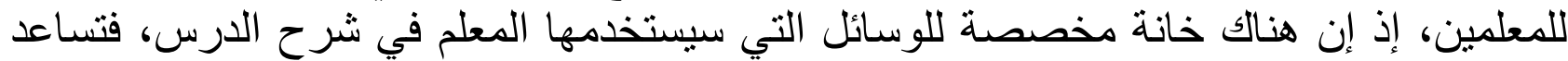

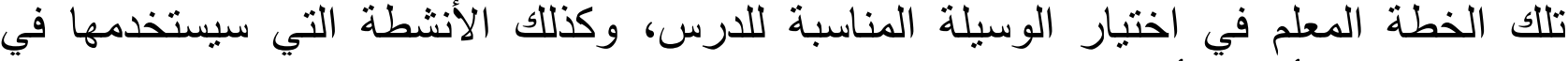
الدرس، ويذكر أيضًا بأن بعض المناهج الحديثة تقوم بتحديد الوسائل التعليمية التي سيحتاجها

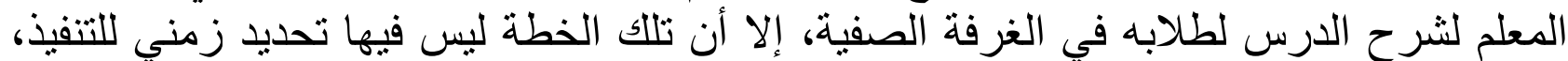

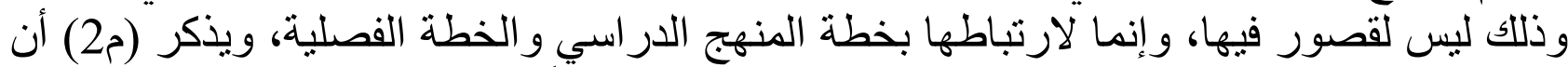

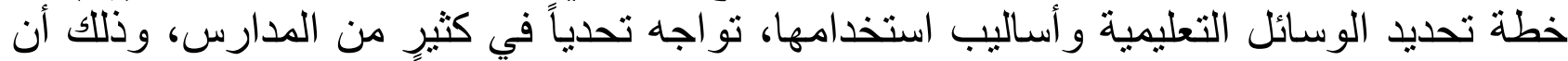

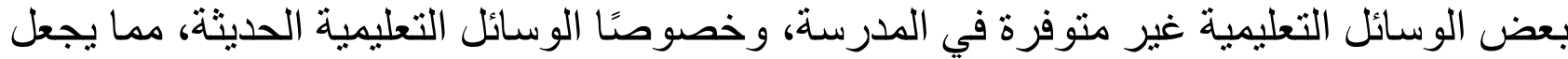

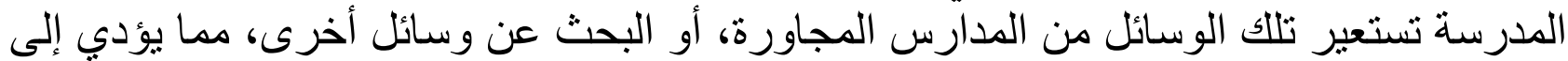

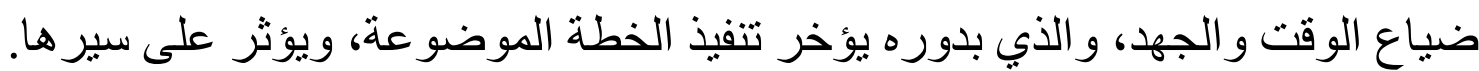

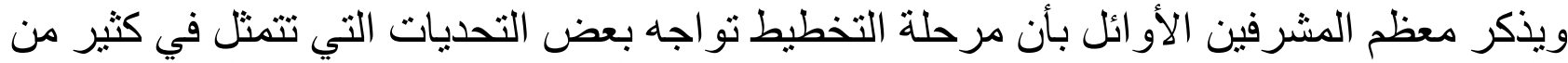

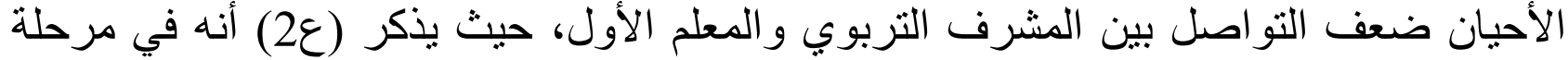

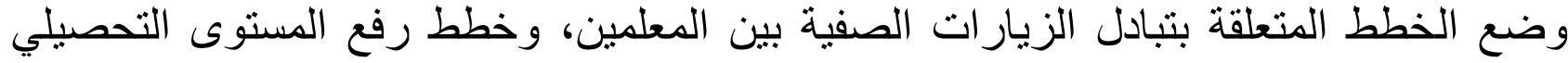

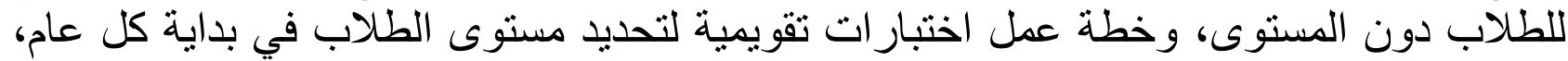

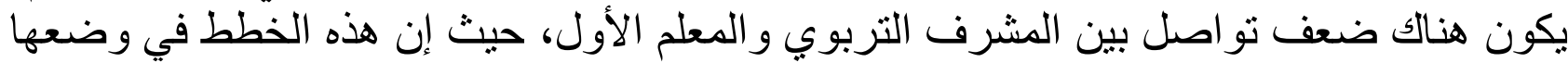

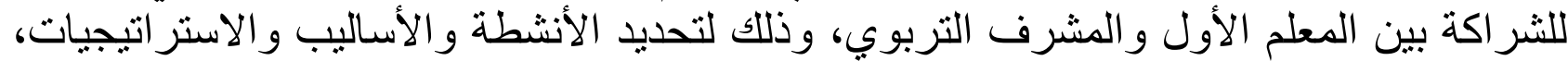

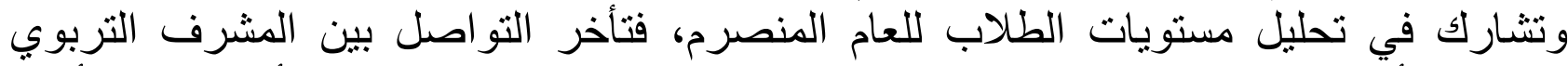

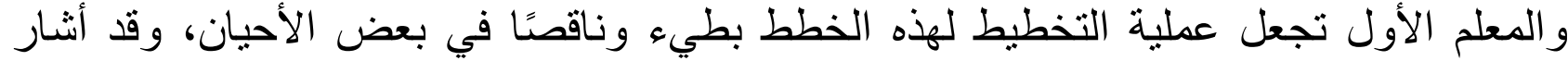

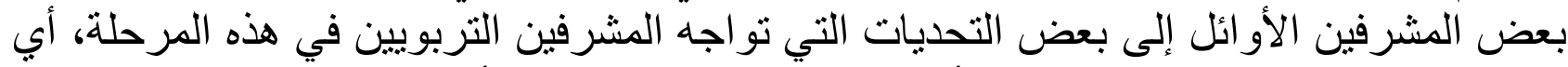

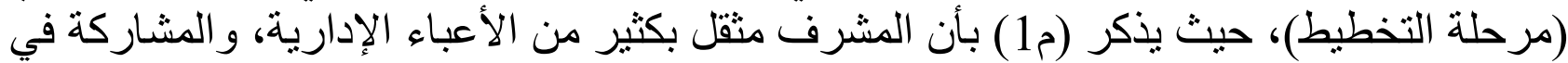

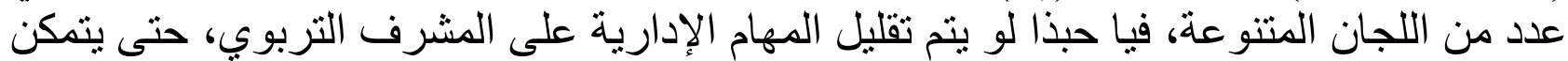

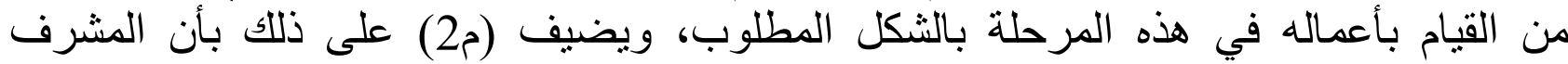

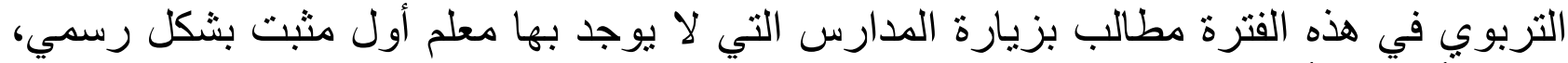

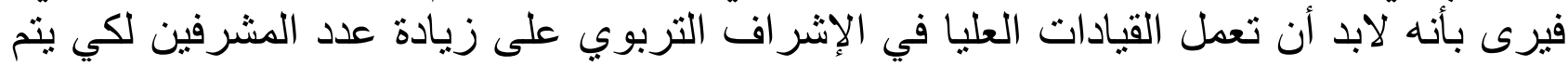
تقليل نصاب كل مشرف نربوي لانب من المدارس. المجال الثالث (التفيذ والمتابعة الميدانية):

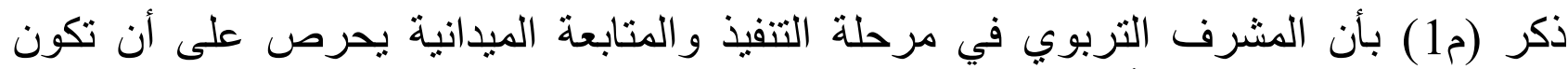

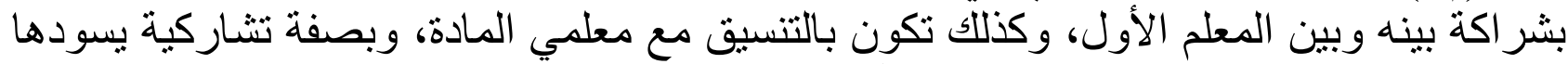

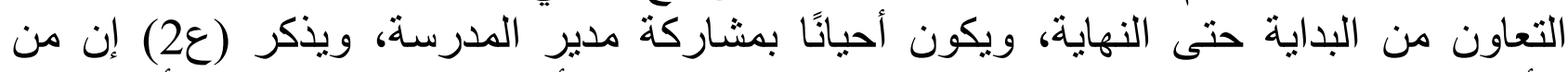

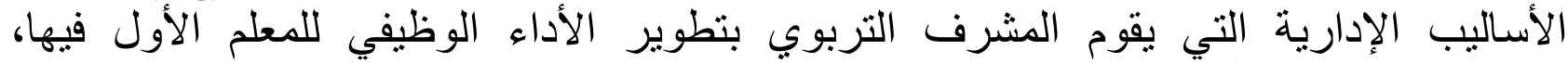

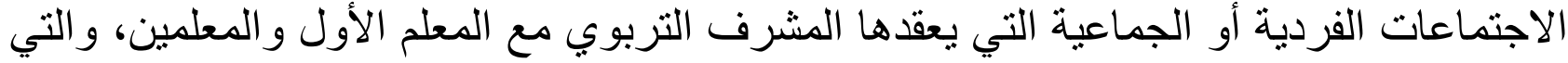


تتيح لهم الفرصة عن التعبير عن احتياجاتهم في عمليات التنفيذ، والتعبير عن النواقص التص التي وني

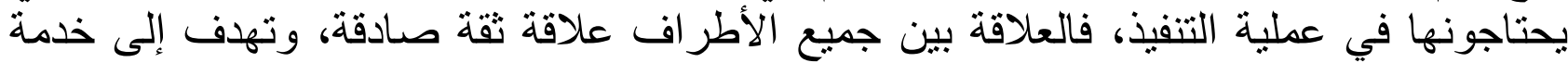

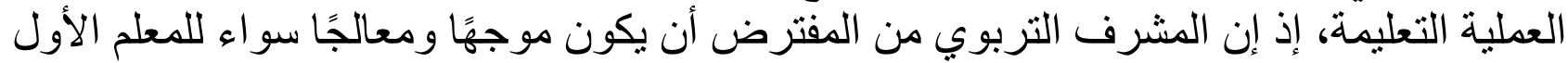

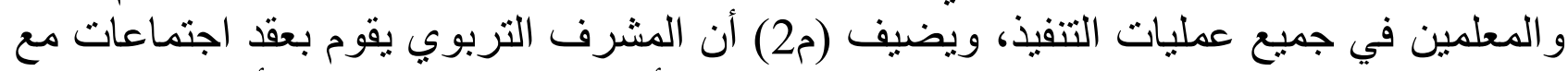

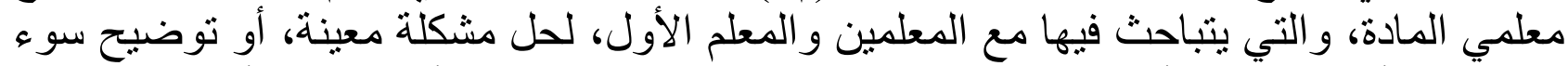

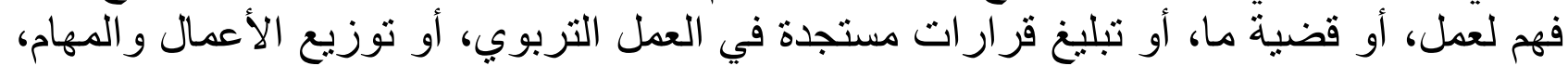

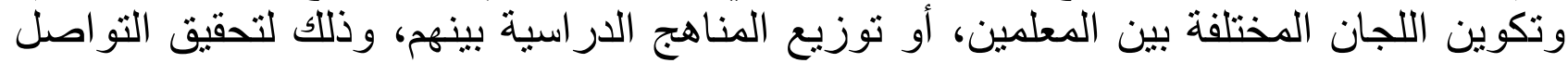

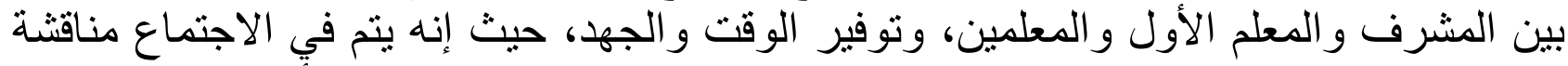

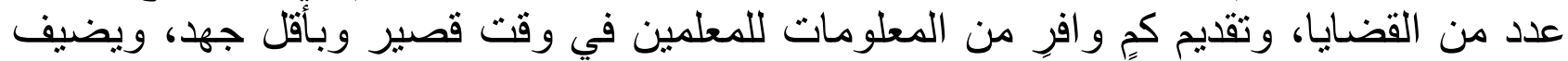

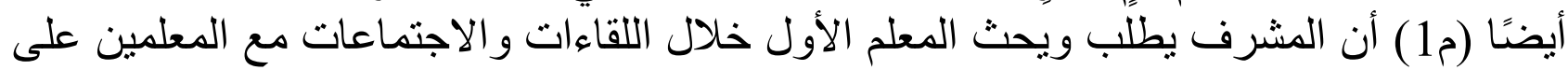

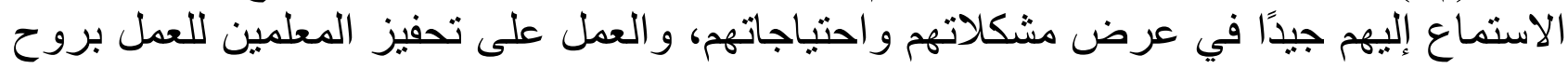

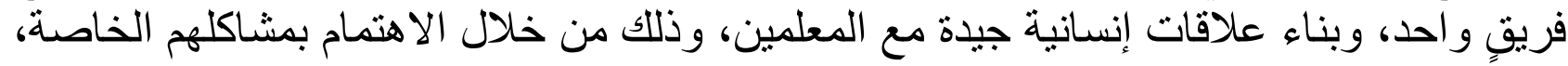

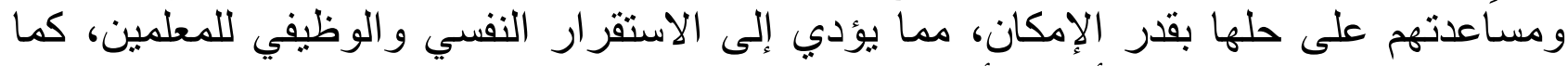

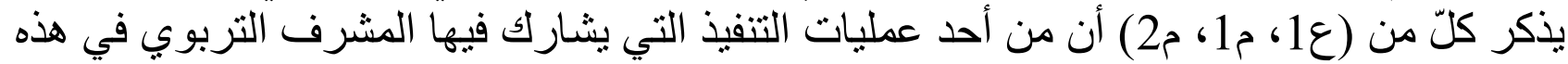

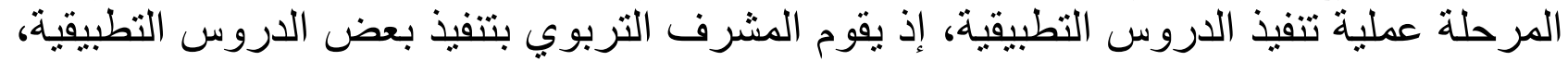

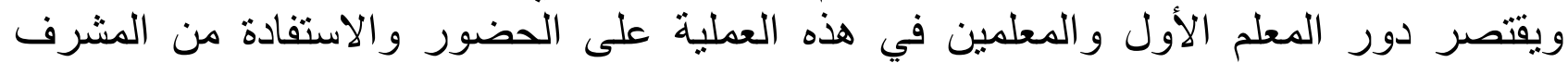

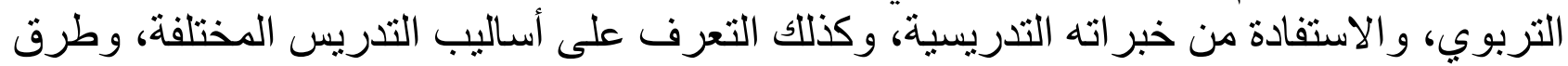

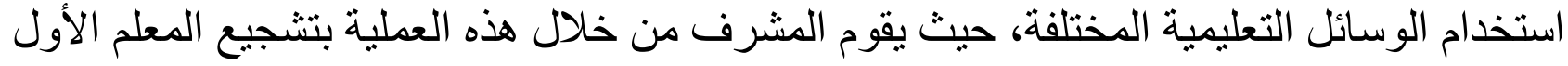

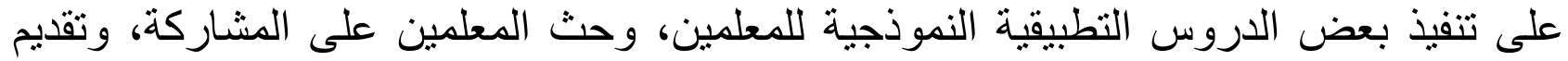

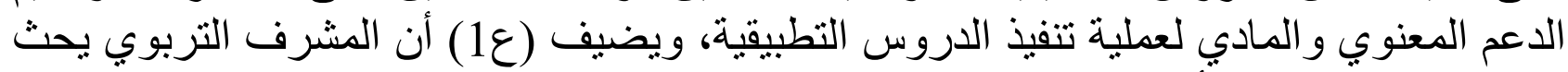

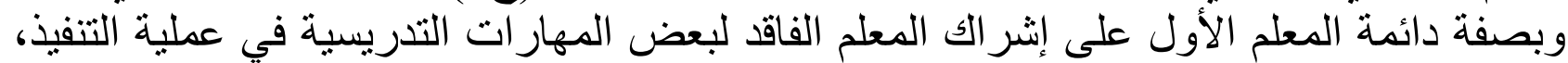
وذلك لتعزيز نقة المعلم بنفسه، و التخلص من التن عقدة الخوف و القلق.

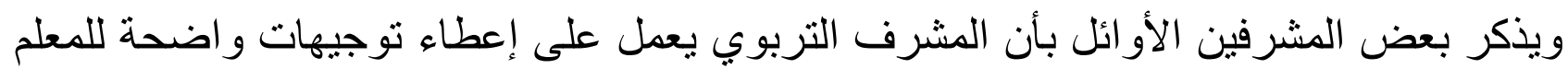

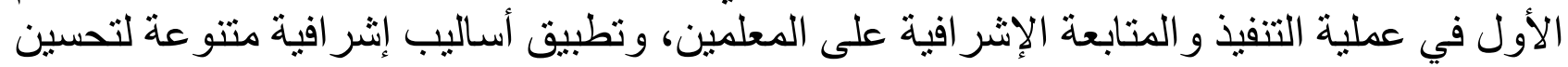

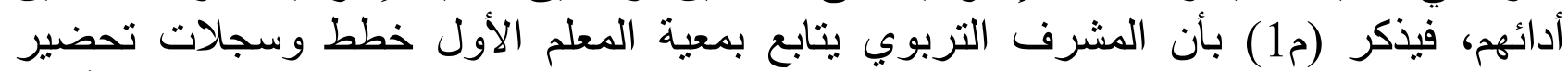

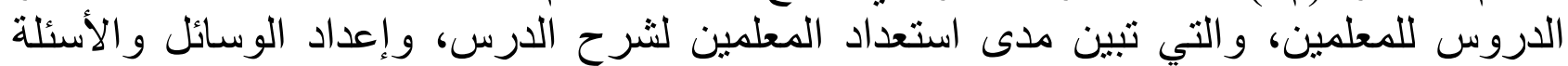

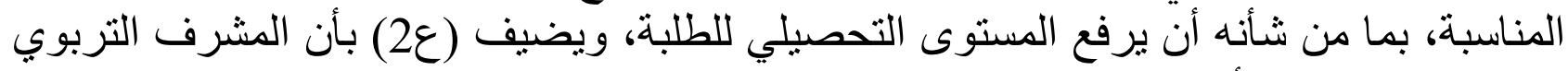

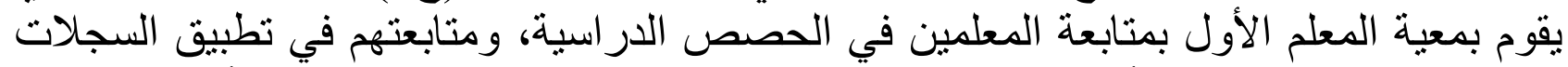

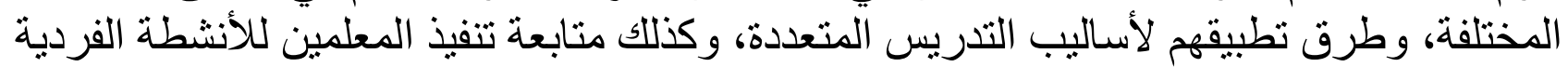

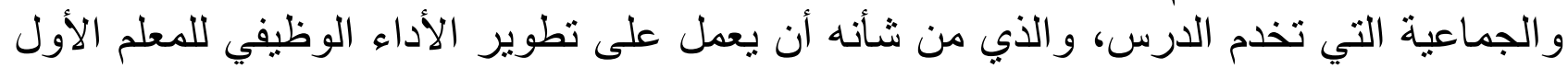

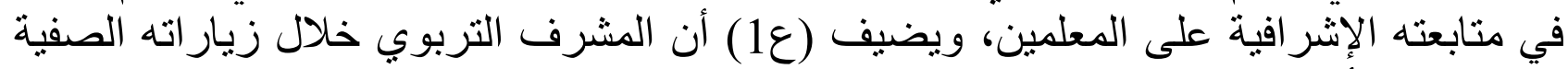

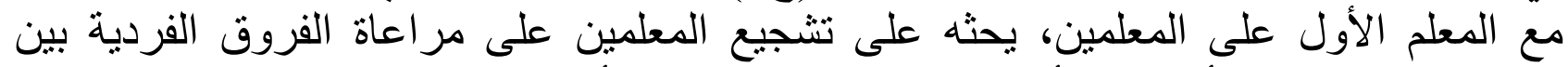

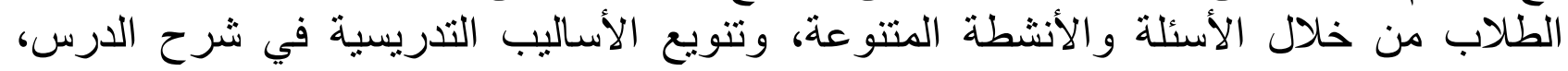

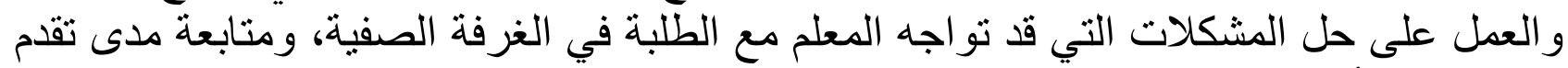
المعلمين في أدائهم المهني.

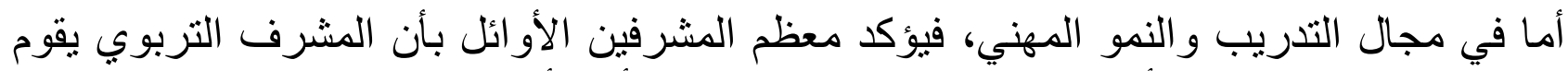

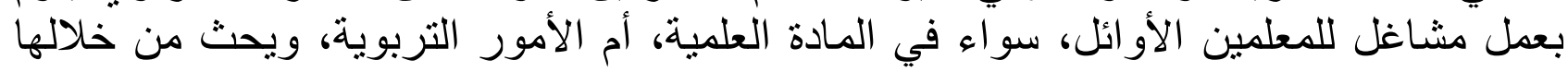




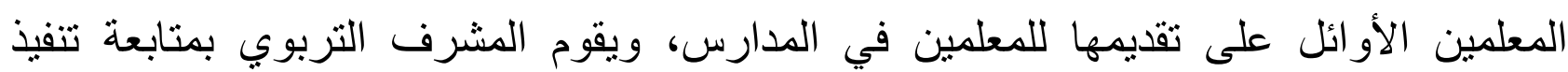

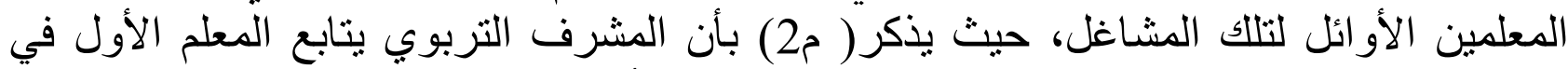

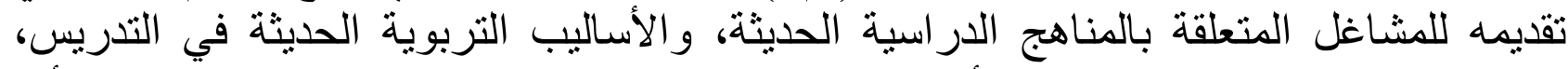

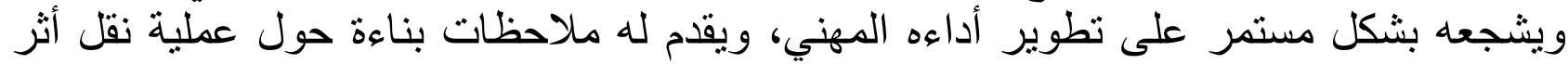

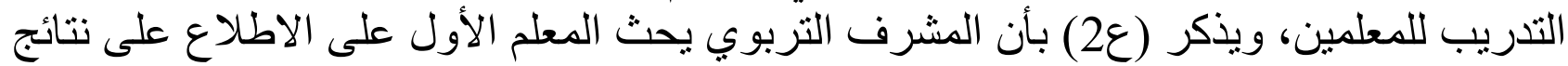

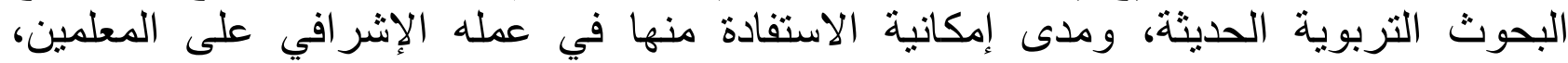

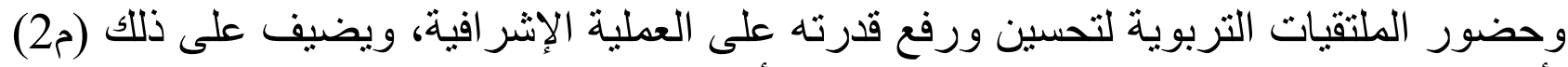

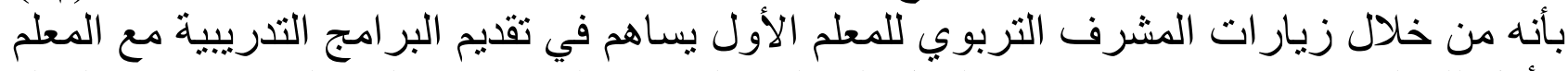

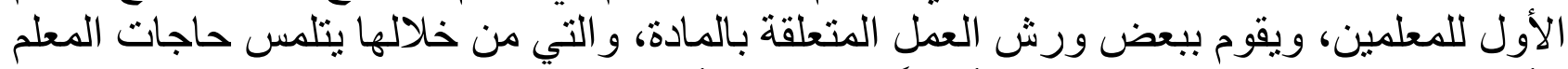

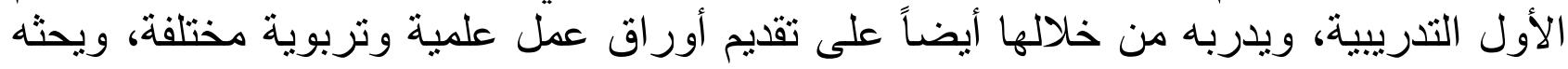

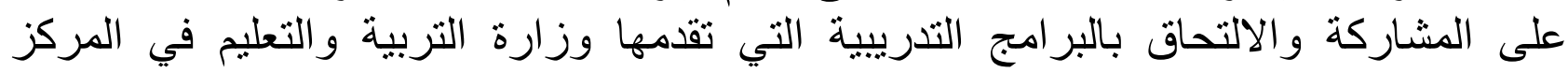

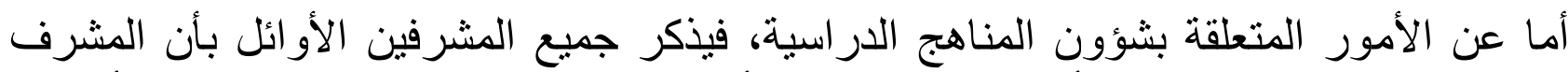

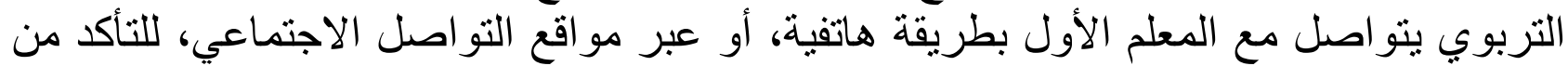

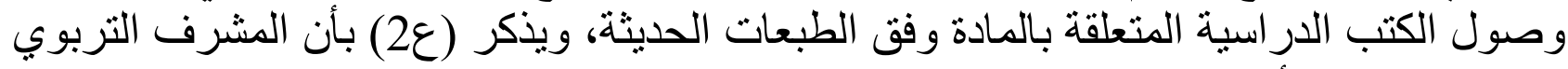

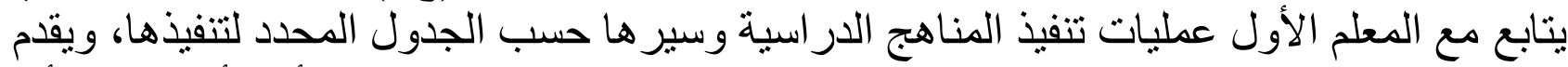

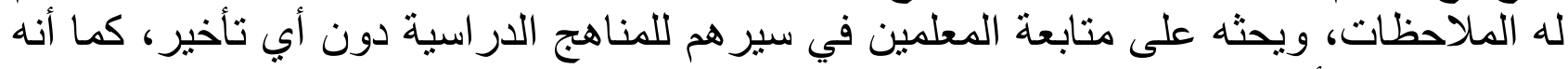

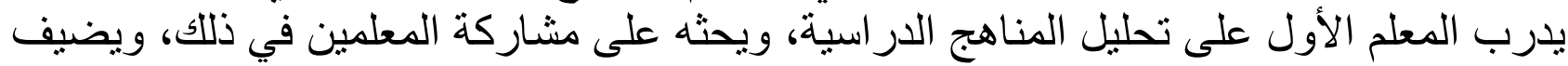

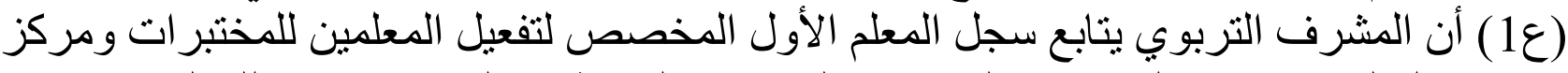

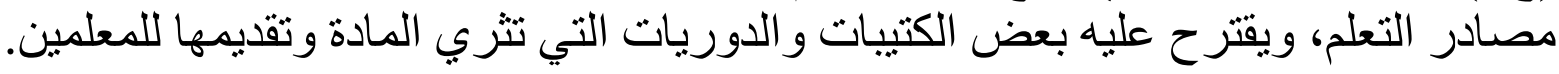

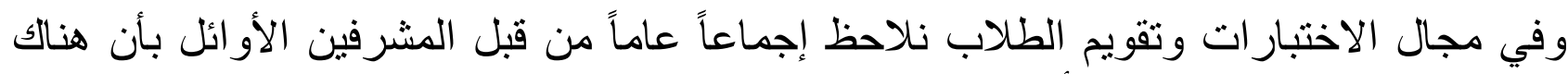

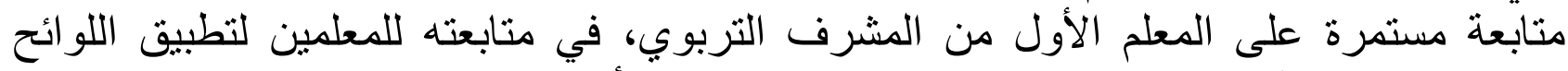

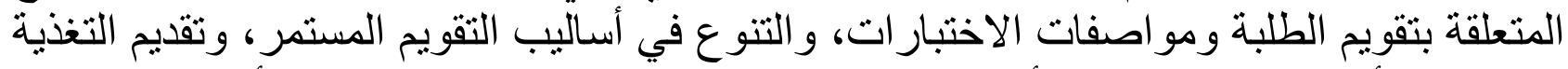

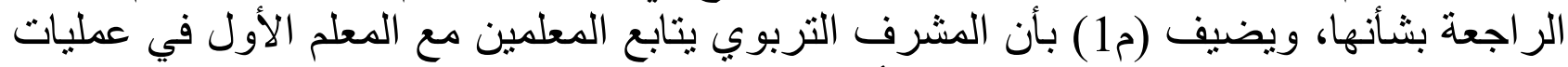

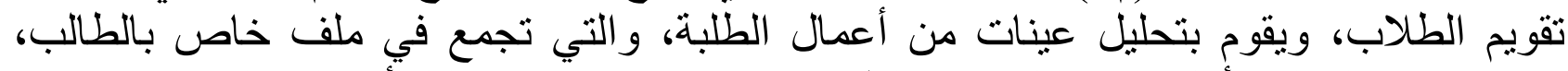
ويتساعد مع المعلم الأول في تحليل نتائج الطلاب في الاختبار اتِ، وتحليل أَعمالهم المختلفة.

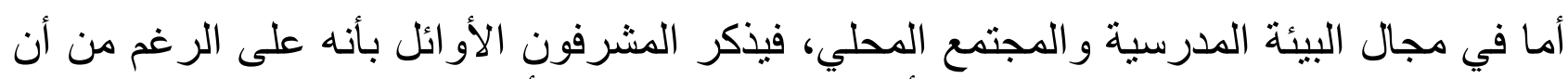

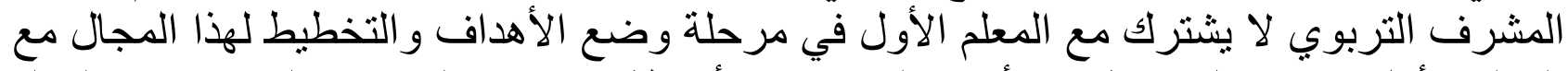

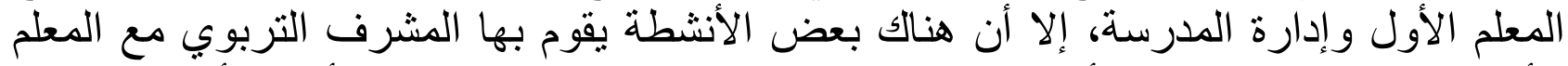

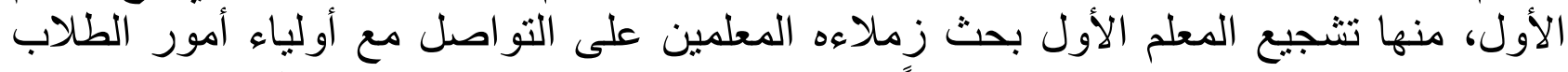

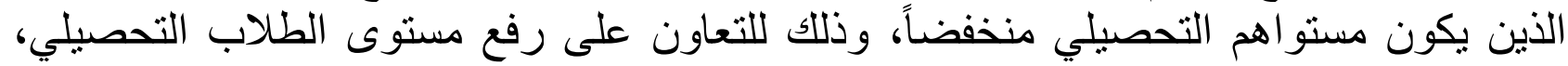
وكذللك حث المعلمين على تنظيم زيار ات ورحلات تعليمية للطلبة.

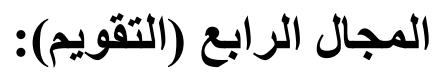

ذكر المشرفون الأو ائل أن الكثير من عمليات التقويم تكون منوازية مع عمليات التنفيذ والمتابعة

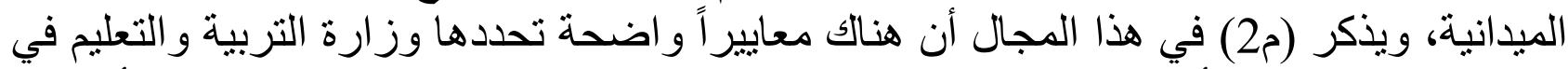

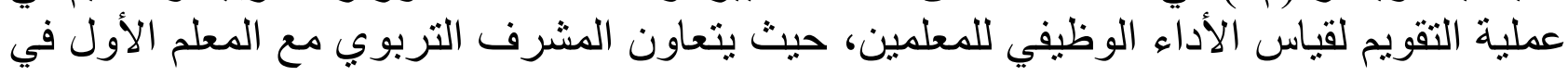


تقويم أداء المعلمين، وقياس مستوى أدائهم العملي للمهام و الو اجبات الموكلة إليهم، وذللك من خلال

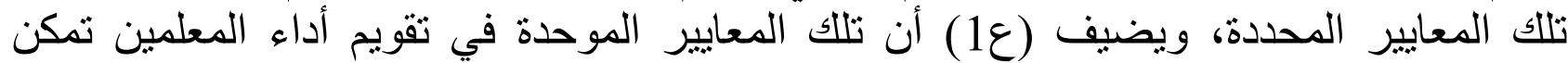

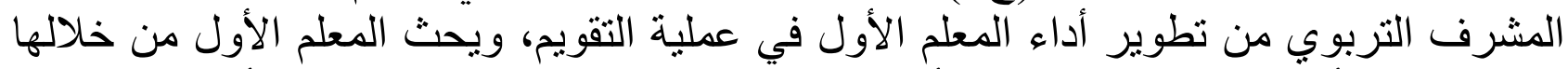

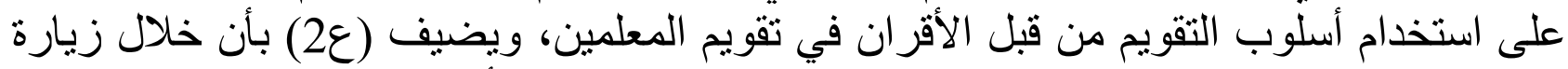

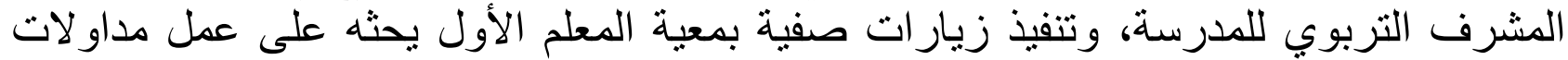

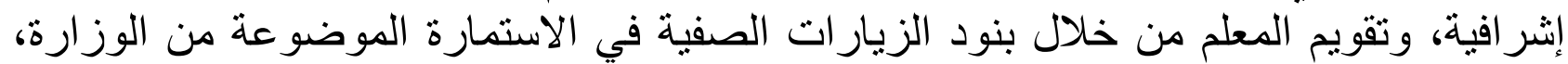

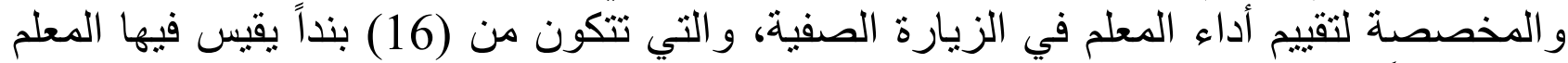

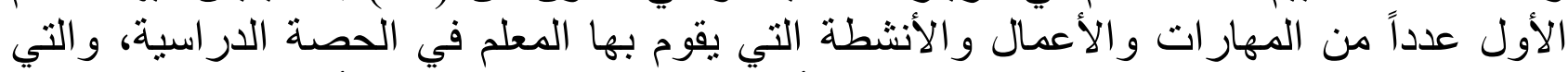

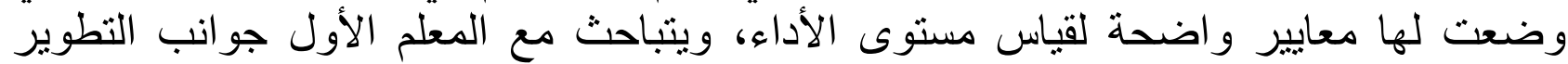

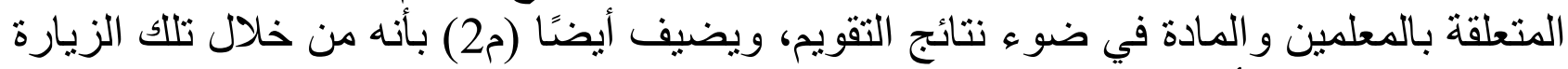

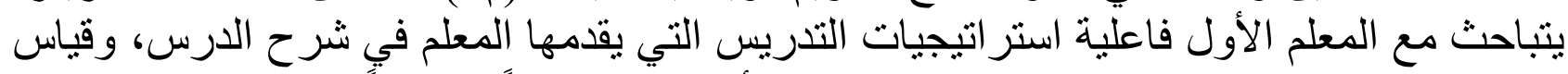

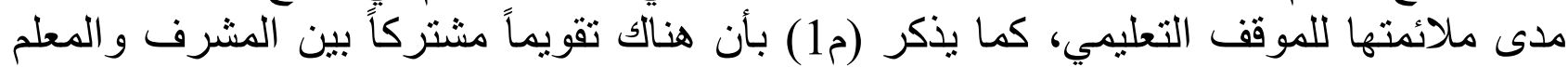

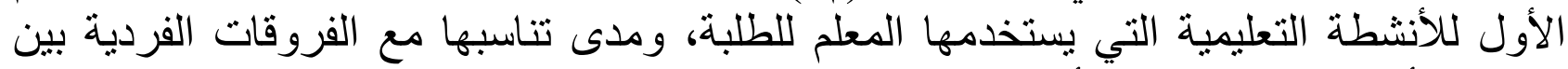

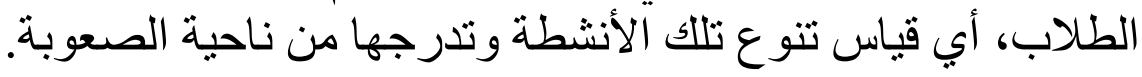

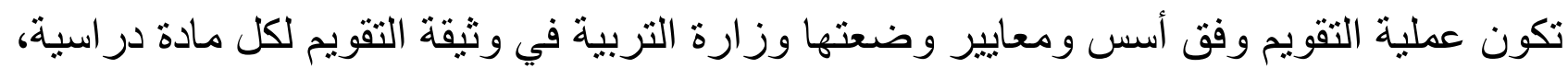

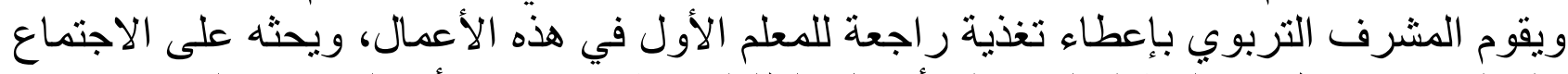

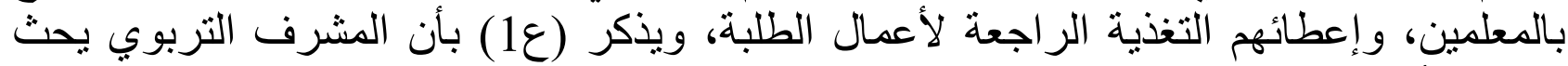

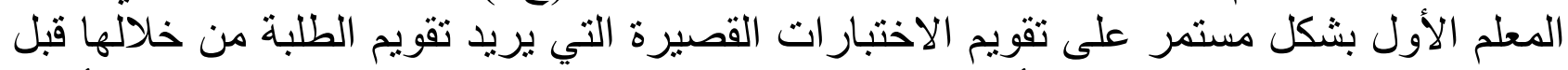

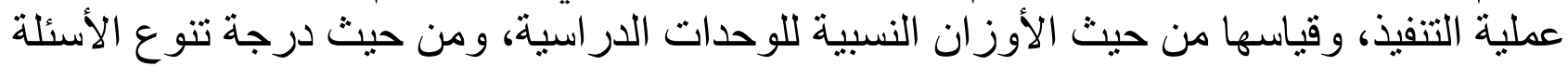

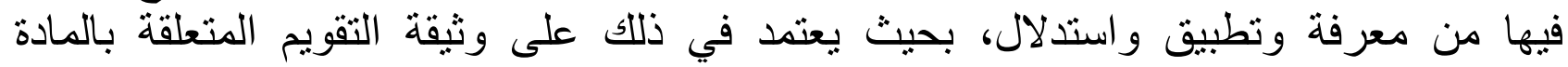

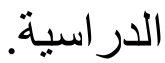

ويذكر المشرفون الأوائل بأن من أعمال التقويم التي يتابع فيها المشرف التربوي المعلم الأول،

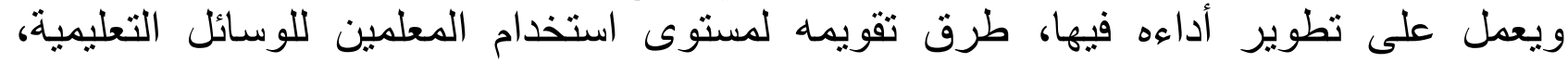

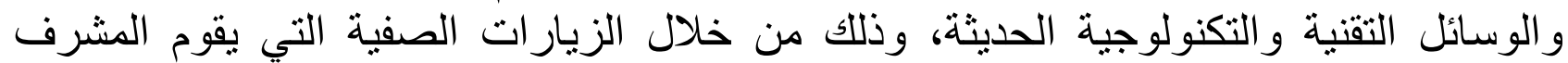

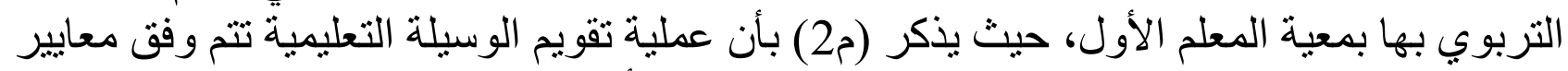

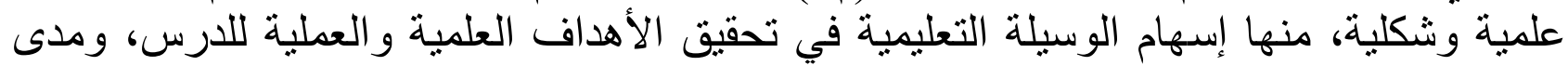

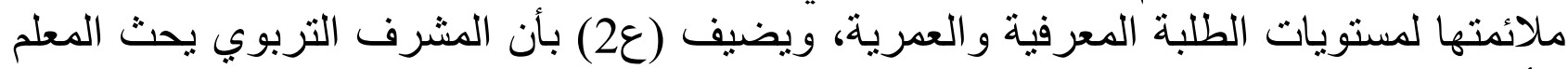
الأول على تقويم استخدام المعلمين للوسيلة التعليمية، وفق المعائية المعايير العلمية لتقويم استخدام الوسائل

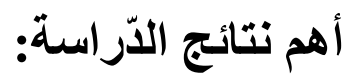

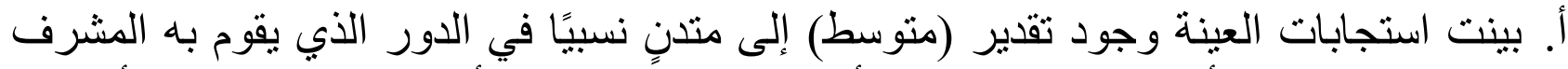

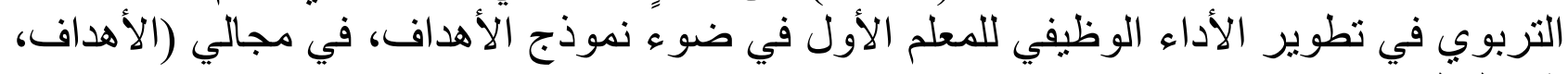
التخطيط).

ب. بينت استجابات العينة أنَّ ممارسة المشرفين التربويين في تطوير الأداء الوظيفي للمعلمين الأو ائل كان بتقدير (عالٍ) في مجالات (التفيذ و المتابعة الميدانية، التقوينم). 
قائمة المصادر و المر اجع:

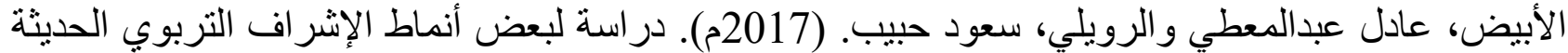

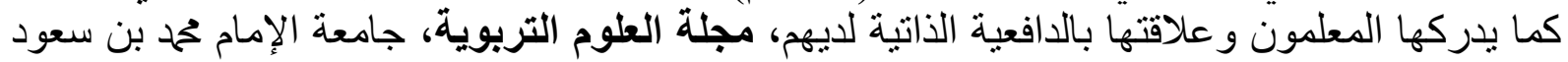
الإسلامية، السعودية، العدد السادس، 103 10 168.

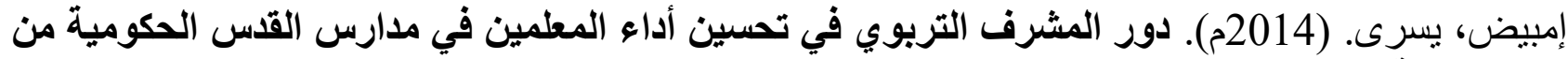
وجهة نظر المعلمين والمديرين، رسالة ماجستير غير منشورة، جامعة بيرزيت، بيرئ فيرزيت، فلسطين.

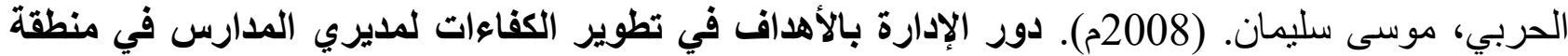

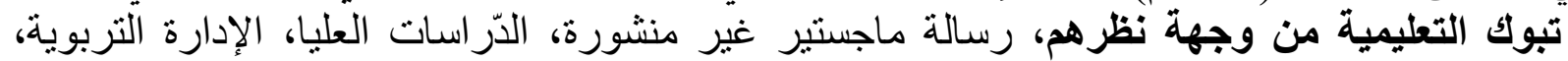
جامعة مؤتة.

الدليمي، طارق. (2016م). الإثراف التربوي واتجاهاته المعاصرة. الأردن: مركز دييونو لتعليم التفكير.

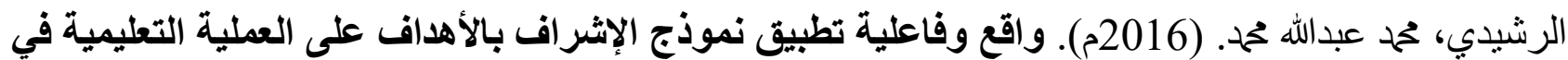

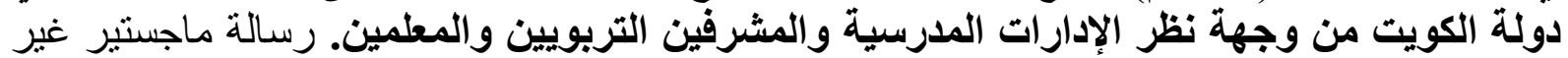
منشورة، كلية العلوم التربوية، جامعة آل البيت.

الثديفات، باسل. (2014م). دور المشرفين التربويين في تطوير الأداء المهني لمعلمي الدّراسات الاجتماعية في

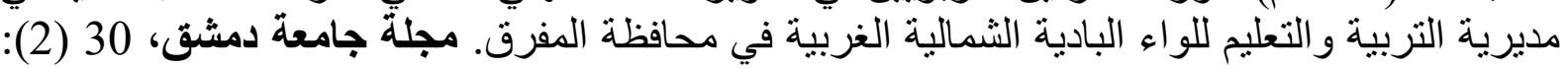
.299-339

الثمري، خالد أحدد. (2017م). درجة نطبيق مديري المدارس الإدارة بالأهداف وسبل تحسينها، مجلة كلية ألتربية الأساسية للعطوم التربوية والإنسانية، العدد 31، 141- 158 الإدارة

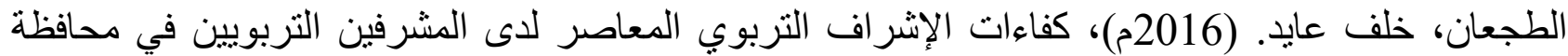

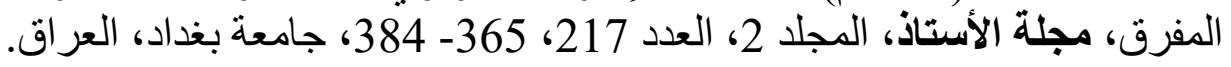

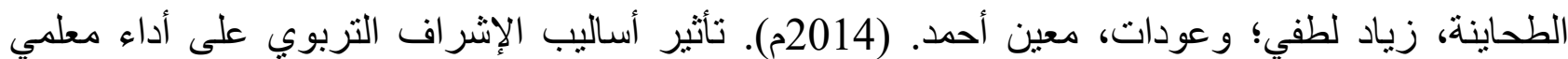
التربية الرياضية في الددارس الحكومية الأردنية (نسخة إلكترونية)، مجلة العلوم التربية التربوية والتئية النفسية،

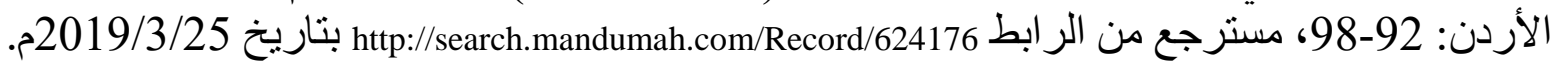

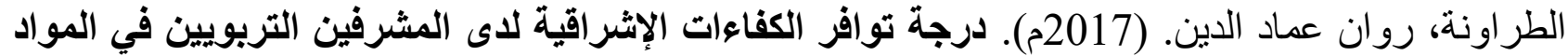

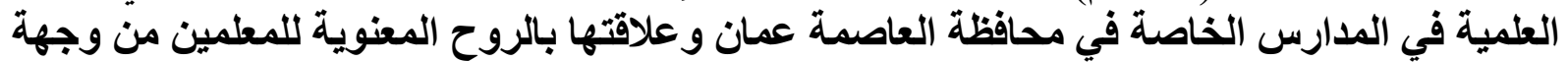
نظرهم، رسالة ماجستير غير منشورة، كلية العلوم التربوية، جامعة الثرق الثرانية الأوسط، عمان: الأردن.

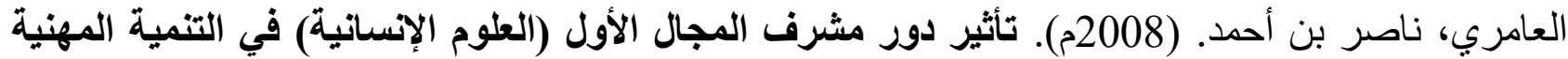
للمعلمات بالحلقة الأولى من التعليم الأساسي بسلطنة عمان. رسالة ماجستير غير منشورة، كلية التربية، جامعة عين شمس، مصر.

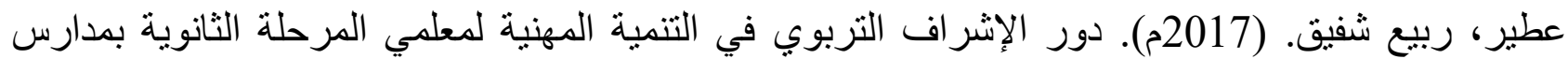

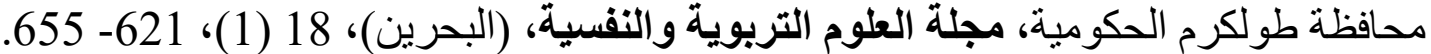

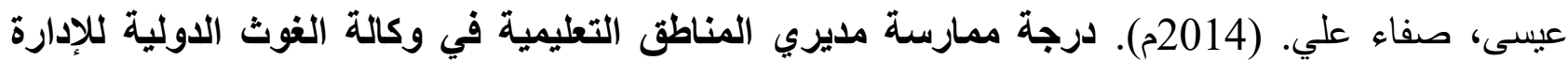

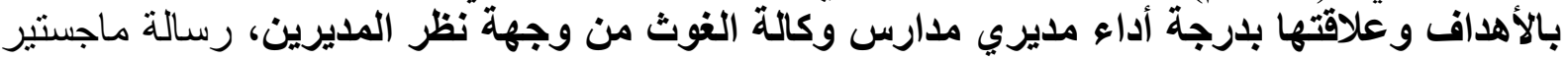

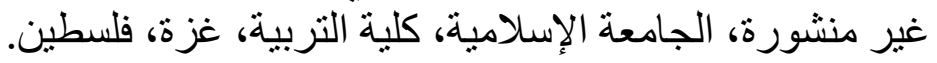

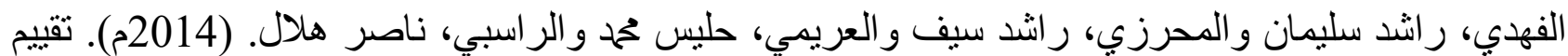
الهيئة الإشر افية والإدارية لنطبيق منظومة الإشراف التربوي وآليات تنفيذها في سلطنة عمان، مجلة 


\section{العلوم النفسية والتربوية، 15(3)، 297-327.}

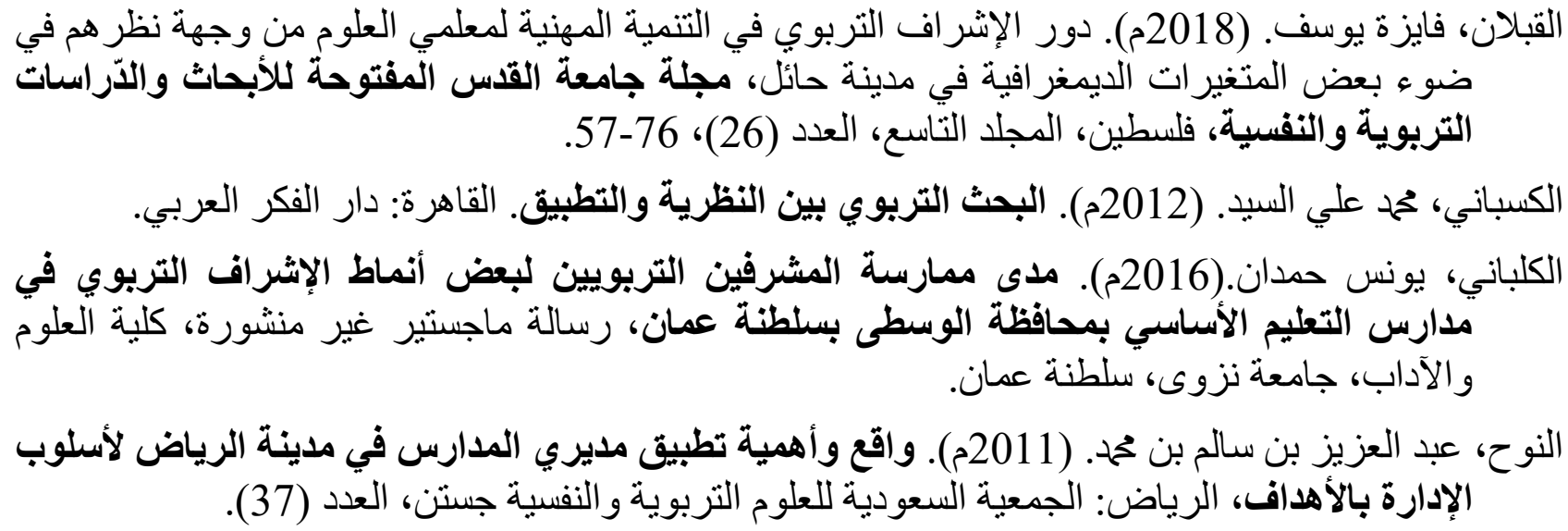

\section{ARABIC REFERENCES IN ROMAN ALPHABETS}

Al'abyd, Eadil Ebdalmety Walruwiliu, Sueud Hubib. (2017m). Dirasat Libaed 'Anmat Al'iishraf Altarbuii Alhadithat Kama Yudrikuha Almuelimun Waealaqatuha Bialdaafieiat Aldhdhatiat Ladayhim, Majalat Aleulum Altarbawiati, Jamieat Al'imam Muhamad Bin Sueud Al'iislamiat, Alsaeudiat, Aleadad Alsaadis, 103- 168.

'limbid, Yusaraa. (2014ma). Dawr Almushrif Altarbawii Fi Tahsin 'Ada' Almuealimin Fi Madaris Alquds Alhukumiat Min Wijhat Nazar Almuealimin Walmadirina, Risalat Majstayr Ghyr Manshurat, Jamieat Birzit, Biarzit, Filastin.

Alharbi, Musaa Suliman. (2008ma). Dawr Al'iidarat Bial'ahdaf Fi Tatwir Alkufaa'at Limudiri Almadaris Fi Mintaqat Tbwk Altaelimiat Min Wijhat Nazarihim, Risalat Majsatayr Ghyr Minshurat, Alddrasat Aleulya, Al'iidarat Altarbawiati, Jamieatan Mutat.

Aldalimiu, Tariq. (2016ma). Al'iishraf Alturbwi Waitijahath Almueasirat. Al'ardun: Markaz Dibunu Litaelim Altafkir.

Alrashidiu, Muhamad Eabdallh Mahmid. (2016ma). Waqie Wafaeiliat Tatbiq Namudhaj Al'iishraf Bial'ahdaf Ealaa Aleamaliat Altaelimiat Fi Dawlat Alkuayt Min Wijhat Nazar Al'iidarat Almadrasiat Walmushrifin Altarbuiiyn Walmuelimina. Risalat Majstayr Ghyr Manshurati, Kuliyat Aleulum Altarbawiati, Jamieat Al Albayt.

Alshadifat, Basil. (2014ma). Dawr Almushrifin Altarbuiiyn Fi Tatwir Al'ada' Almahnii Limuelami Alddrasat Alaijtimaeiat Fi Mudiriat Altarbiat Waltaelim Lilwaa' Albadiat Alshamaliat Algharbiat Fi Muhafazat Almafraq. Majalat Jamieat Dimushq, 30 (2): 339-299.

Alshamriu, Khalid 'Ahmid. (2017ma). Darajat Tatbiq Mudiria Almadaris Al'iidarat Bial'ahdaf Wasubul Tahsiniha, Majalat Kuliyat Altarbiat Al'asasiat Lileulum Altarbawiat Wal'iinsaniati, Aleadad 31, 141 158.

Altajean, Khalf Eayd. (2016m), Kaffa'at Al'iishraf Altarbuii Almueasir Ladaa Almushrifin Alturbuiiyn Fi Muhafazat Almafraqi, Majalat Al'ustadh, Almujalid 2, Aleadad 217, 365- 384,

Jamieatan Baghdad, Aleiraq. Altahaynat, Ziad Litafy; Waeawdat, Mueayan 'Ahmad. (2014m). Tathir 'Asalib Al'iishraf Altarbwii Ealaa 'Ada' Muelimi Altarbiat Alriyadiat Fi Almadaris Alhukumiat Al'urduniya (Nsakhat 'liliktruniat), Majalat Aleulum Altarbawiat Walnafsiati, Al'ardun: 92-98, Mustarjae Min Alraabut Http://Search.Mandumah.Com/Record/624176 Bitarikh 25/3/2019m.

Altarawnatu, Rawan Eimad Aldiyn. (2017ma). Darajat Tuafir Alkufaa'at Al'iishraqiat Ladaa Almushrifin Altarbuiiyn Fi Almawadi Aleilmiat Fi Almadaris Alkhasat Fi Muhafazat Aleasimat Eamman Waealaqatuha Bialruwh Almaenawiat Lilmuelimin Min Wijhat Nazarihim, Risalat Majstayr Ghyr Manshurati, Kuliyat Aleulum Altarbawiati, Jamieat Alshrq Al'awsati, Eamana: Al'urdunn.

Aleamiriu, Nasir Bin 'Ahmad. (2008m). Tathir Dawr Musharaf Almajal Al'awal (Aleulum Al'iinsaniata) Fi Altanmiat Almihniat Lilmuealamat Bialhulqat Al'uwlaa Min Altaelim Al'asasii Bisiltanat Euman. Risalat Majstayr Ghyr Manshurati, Kuliyat Altarbiati, Jamieat Eayan Shams, Misr.

Eatir, Rbye Shafiq. (2017ma). Dawr Al'iishraf Altarbawii Fi Altanmiat Almihniat Limuelimi Almarhalat 
Alththanawiat Bimadaris Muhafazat Tulkarm Alhukumiati, Majalat Aleulum Altarbawiat Walnafsiati, (Albahrayn), 18 (1), 621 - 655.

Eisaa, Safa' Eali. (2014ma). Darajat Mumarasat Mudiriu Almanatiq Altaelimiat Fi Wikalat Alghawth Alduwaliat Lil'iidarat Bial'ahdaf Waealaqatiha Bidarajat 'Ada' Mudiri Madaris Wikalat Alghawth Min Wijhat Nazar Almadirina, Risalat Majsatayr Ghyr Minshurat, Aljamieat Al'iislamiati, Kuliyat Altarbiati, Ghazat, Filastin.

Eisaa, Safa' Eali. (2014ma). Darajat Mumarasat Mudiriu Almanatiq Altaelimiat Fi Wikalat Alghawth Alduwaliat Lil'idarat Bial'ahdaf Waealaqatiha Bidarajat 'Ada' Mudiri Madaris Wikalat Alghawth Min Wijhat Nazar Almadirina, Risalat Majsatayr Ghyr Minshurat, Aljamieat Al'iislamiati, Kuliyat Altarbiati, Ghazat, Filastin.

Alfahdi, Rashid Sulayman Walmahrizi, Rashid Sayf Walearimi, Halis Muhamad Walraasibi, Nasir Hulal. (2014ma). Taqyim Alhayyat Al'iishrafiat Wal'iidariat Litatbiq Manzumat Al'iishraf Altarbwii Waliat Tanfidhuha Fi Saltanat Eumaan, Majalat Aleulum Alnafsiat Waltarbiwiat, 15(3), 297-327.

Alqablan, Fayzt Yusif. (2018ma). Dawr Al'iishraf Altarbawii Fi Altanmiat Almihniat Limuelimi Aleulum Min Wijhat Nazarihim Fi Daw' Bed Almutaghayirat Aldiymighrafiat Fi Madinat Hayili, Majalat Jamieat Alquds Almaftuhat Lil'abhath Walddrasat Altarbawiat Walnafsiati, Filastin, Almujalid Altaasie, Aleadad (26), 76-57.

Alkusbanii, Muhamad Ealia Alsayd. (2012ma). Albahth Altarbuiu Bayn Alnazariat Waltatbiqa. Alqahirat: Dar Alfikr Alearabi.

Alkulbani, Yunis Hmdan.(2016ma). Madaa Mumarasat Almushrifin Altarbuiiyn Libaed 'Anmat Al'iishraf Altarbawii Fi Madaris Altaelim Al'asasii Bimuhafazat Alwustaa Bisiltanat Eumaan, Risalat Majstayr Ghyr Manshuratin, Kuliyat Aleulum Waladabi, Jamieat Nazwaa, Saltanat Eaman.

Alnuwhu, Eabd Aleaziz Bin Salim Bin Mahmd. (2011ma). Waqie Wa'ahamiyat Tatbiq Mudirii Almadaris Fi Madinat Alriyad Li'uslub Al'iidarat Bial'ahdafi, Alriyad: Aljameiat Alsewdyt Lileulum Altarbawiat Walnafsiat Jstn, Aleadad (37).

\section{REFERENCES}

Campbell، T. F. (2013). Teacher supervision and evaluation: a case study of administrators' and teachers' perceptions of mini observations، Estern North University ، Boston.

Chen، C. W. Y.، \& Cheng، Y. S. (2013). The Supervisory Process of EFL Teachers: A Case Study. TESL-EJ، 17(1)، n1 .Taiwan..

Lindberg، E. (2011). Effects of management by objective at :studies of Swedish of upper secondary school and the influence of role stress and self-efficacy on school leaders. school of business، Umea university، Sweden .

LOPEZ، M. C. A. (2016). Classroom Supervisory Practices and Their Relationship to Teacher Effectiveness As Perceived By Secondary Teachers. SMCC Higher Education Research Journal، 2(1)، 1-1.

Määttä، K.، Uusiautti، S.، \& Alila، S. (2016). The Principles and Practices of Supervision That Supports the Development of Inclusive Teacherhood. Journal of Education and Learning ، 5(3) 297-309.

Mohammed، B. (2015). The role of educational inspectors in curriculum implementation in public secondary schools: A case of Bauchi State، Nigeria. Unpublished Med Thesis.

Rahabav، P. (2016). The Effectiveness of Academic Supervision for Teachers. Journal of Education and Practice، 7(9)، 47-55.

Sule، M. A.، Eyiene، A.، \& Egbai، M. E. (2015). Instructional supervisory practices and teachers' role effectiveness in public secondary schools in Calabar South Local Government Area of Cross River State، Nigeria. Journal of Education and Practice، 6(23)، 43-47.

Wenceslaus، O. (2010) Relevance and benefits of management by objectives to secondary school management in Anambra State: Teachers views، International Journal of Educational Administration and Policy Studies، Vol 2، ( 7 )، pp $99-104$. 